\title{
»VIDENSKABELIG SOCIALISME«, HVAD ER DET?
}

\author{
Alexa Mohl
}

Få af verdenslitteraturens værker, er blevet så heftigt diskuteret som Marx' skrifter. Det er ikke kun tilhængere og modstandere af Marx, der har stredes og stadig strides om den rigtige fortolkning af hans værker. I hver af disse lejre har man været og er man stadigt i totterne på hinanden. Kun med hensyn til en ting er tilhængere og modstandere af samtlige tolkninger enige med Marx og Engels: Marx' studier og analyser skulle levere den »teoretiske begrundelse for kommunismen $\ll^{1}$; »Kapitalen « ville »give stræbenen mod socialismen et videnskabeligt grundlag $\ll^{2}{ }^{2}$

\section{I}

Det var en kilde til stolthed hos de foragtede i det borgerlige samfund og hos de af deres partikammerater, der kom fra modstanderens lejr, at socialismen med udfoldelsen af kritikken af den politiske økonomi i Marx' hovedværk var forvandlet fra utopisk drøm om menneskehedens fremtid til videnskab. I sikker tiltro til sin teoretiske uangribelighed tilråber det tyske socialdemokratis førende hoved Karl Kautsky de tyske lærestoles Marx- og marxismekritikere: »Den som vil påvise det fejlagtige i vor målsætning må bevise, at vor lære om den $\varnothing$ konomiske udvikling er falsk ... $\ll^{3}$

1. Marx til Ferdinand Lassalle 6. nov. 1859, MEW 29, s. 618.

2. Friedrich Engels: Rezension des Ersten Bandes »Das Kapital« für die »Elberfelder Zeitung « MEW 16, s. 215.

3. Karl Kautsky: Das Erfurter Programm in seinem grundsätzlichen erläutert. 10 oplag, Stuttgart 1910, s. 131 
Det program, som partiet efter tolv års forfølgelse og illegalitet under socialistlovgivningen vedtager i Erfurt 1891, støtter sig da også til Karl Marx’ videnskabelige hovedværk. Kautsky, fra hvis pen programmets teoretiske del kom, bekræfter dette i forordet til femte oplag af sine kommentarer: »... den almene del af selve programmet er blot en omskrivning af det kendte afsnit om »den kapitalistiske akkumulations historiske tendens i »Kapitalen «. ${ }^{4}$ I et brev til Wilhelm Liebknecht ${ }^{5}$ fra 1871 havde Marx selv henvist til dette kapitel om den oprindelige akkumulation som en passende tekst til praktisk propaganda. Kapitlet indeholder da også det eneste »sted « i Marx' hovedværk, hvor den proletariske revolution tematiseres som resultatet af det borgerlige samfunds udviklingslove. Marx beskriver dér kapitalforholdets udviklingslove med udgangspunkt i dets forhistorie, d.v.s. »ekspropriationen af de umiddelbare producenter ${ }^{6}{ }^{6}$, eller adskillelsen af producent og produktionsmiddel. Videre beskriver han den fortsatte ekspropriation af privatejendom »gennem udfoldelsen af den kapitalistiske produktionsmådes egne immanente lovmæssigheder, gennem kapitalens centralisering $~^{7}$ frem til det punkt, hvor denne proces igen slår om: »Med det stadigt faldende antal kapitalmagnater, der tilraner sig og monopoliserer alle fordele ved denne transformationsproces, vokser mængden af elendighed, undertrykkelse, trældom, degeneration, udbytning, men også vreden hos arbejderklassen, der er i stadig rivende vækst og som gennem selve den kapitalistiske produktionsproces' mekanisme er blevet skolet, forenet og organiseret. Kapitalmonopolet bliver til lænker for den produktionsmåde, der er blomstret op sammen med og under det. Produktionsmidlernes centralisering og arbejdets samfundsmæssiggørelse når et punkt, hvor de bliver uforenelige med deres kapitalistiske hylster. Det bliver sprængt. Den kapitalistiske privatejendoms time slår. Ekspropriatørerne eksproprieres. $\ll^{8}$

Ifølge Kautsky, hvis tolkning af Marx gjaldt som den officielle socialdemokratiske teori, findes i det her citerede afsnit argumenterne for det »naturnødvendige « $\mathrm{i}$ en proletarisk revolution med socialismen til følge. De stadigt skærpede krisetendenser i den kapitalistiske produktion og dens endelige sammenbrud $\mathrm{g} \emptyset \mathrm{r}$ en ny samfundsorden med en radikal anden strukturering og sammenfatning af det samfundsmæssige totalarbejde nødvendig. Den tiltagende elendighed tvinger uundgåeligt proletariatet til at gøre oprør mod systemet og sluttelig til at omvælte den kapitalistiske produktionsmåde. Ud over dis-

\footnotetext{
4. samme sted s. XX

5. Marx til Wilhelm Liebnicht 13. april 1871, MEW 33, s. 207.

6. Karl Marx: Das Kapital 1. bind, MEW 23, s. 789. Dansk udgave s. 1058.

7. Samme sted s. 790 , dansk udgave s. 1060

8. Samme sted s. $790 \mathrm{f}$, dansk udgave s. $1060 \mathrm{f}$.
} 
se argumenter, som senere blev diskuteret under betegnelsen sammenbrudsog elendiggørelsesteori, indeholder ovennævnte afsnit endnu en tese, ifølge hvilken den kapitalistiske produktionsmåde selv frembringer de materielle forudsætninger for en ny og højere samfundsorden gennem produktionsmidlernes centralisering og arbejdets samfundsmæssiggørelse: Universalisme- eller socialismetesen. ${ }^{9}$

Disse tre elementer: Sammenbrudsteorien, elendiggørelsesteorien og socialismetesen udgør, når de stykkes sammen, en entydig objekivistisk revolutionsteori, som påviser den uundgåelige proletariske omvæltning af den borgerlige samfundsorden gennem en videnskabelig analyse af den kapitalistiske vareproduktions bevægelseslove. Teorien fremstiller altså en typisk naturvidenskabelig »kausal« begrundelse for den socialistiske revolution.

Opfattelsen af at den proletariske revolution og etableringen af en socialistisk samfundsorden var en nødvendighed i objektiv forstand, d.v.s. at der kunne føres videnskabelig bevis derfor, var ikke alene karakteristisk for kautskyanismen. Rosa Luxemburg delte også denne opfattelse. Således indvendte hun f.eks. overfor Bernstein's kritik af krise- og sammenbrudsteorien: »Antager man ... som Bernstein, at den kapitalistiske udvikling ikke går mod sin egen undergang, så er socialismen ikke længere en objektiv nødvendighed. $\ll^{10}$ Det tyske socialdemokratis socialistiske program ville da kun kunne begrundes idealistisk $» .$. mens den objektive nødvendighed, d.v.s. en begrundelse gennem den materielle udviklings gang, falder væk. « ${ }^{11}$ Det, det drejer sig om for Rosa Luxemburg i denne antikritik, er i virkeligheden mulighederne for at realisere en samfundsmæssig emancipation. Ved at erklære socialismen for et ideal og ikke en historisk nødvendighed er det tyske socialdemokrati »... lykkeligt nået frem til retfærdighedens princip denne gamle traver, som

9. Universalisme - eller socialismetesen betyder hos Marx, at den revolution, som afslutter den kapitalistiske epoke, ikke bringer de partikulære interesser, som den tidligere undertrykte klasse har, til almen samfundsmæssig anerkendelse; men at dens indhold er en almen menneskelig emancipation. Kritikerne af den Marx'ske emancipationsteori hævdede her overfor, at der var en modsætning i påstanden om, at denne universelle revolution skulle gennemføres af en partikulær d.v.s. særlig klasse. I »Einleitung zur Kritik der Hegelschen Rechtphilosophie« leverer Marx i realiteten et vist grundlag for en sådan kritik. Kritikerne overser imidlertid at man på den anden side allerede hos den unge Marx finder formuleringer, som giver en modsætningsfri begrundelse for muligheden af en almen menneskelig emancipation og for etableringen af en samfundsorden, der har overvundet menneskets herredømme over mennesket, med udgangspunkt i produktivkræfternes udvikling og arbejdets samfundsmæssiggørelse. Dette gælder f.eks. »Die Deutsche Ideologie«, hvor Marx og Engels fastslår, at tilegnelsen må »altså allerede i dette perspektiv have en til produktivkræfterne og samkvemsformerne svarende universel karakter.« (MEW 3, s. 67).

10. Rosa Luxemburg: Sozialreform oder Revolution, i Politische Schriften I, Frankfurt, Wien 3. oplag 1968, s. 54.

11. Samme sted s. 55 . 
alle verdensreformatorer i årtusinder har benyttet i mangel af et sikrere historisk befordringsmiddel, på den skabede Rosinante, som alle historiens Don Quichott'er har sporet frem til store verdensreformer for i sidste ende kun at hjemføre et blåt øje. $\ll^{12}$

Bernstein fremførte selv ti år tidligere tilsvarende argumenter mod katetersocialisternes kritik af elendiggørelsesteorien. En af Brentanoskolens nationaløkonomer, Gerhart von Schultze- Gävernitz, havde fremsat den tese, at den kapitalistiske produktionsmådes udvikling fra småvirksomheder til storforetagener automatisk ville medføre en forbedring af arbejderens situation. ${ }^{13}$ Herimod sagde Bernstein: »Vi indrømmer kun, at er ... det ... lykkedes at bevise for det første, at arbejderens situation i den engelske bomuldsindustri, hvor stordriften er fremherskende, er - vi siger ikke strålende, men blot tilfredsstillende i forhold til fornuftige krav, og for det andet, at stordriften i sin udbredelse overalt og vedvarende må føre til det samme resultat inden for den bestående samfundsorden, så er socialismen i hovedsagen besejret. $\ll^{14}$

Konklusionen på de af Luxemburg's og Bernstein's teser, der her er trukket frem, er, at uden et sammenbrud i den kapitalistiske vareproduktion og uden proletariatets elendiggørelse vil socialismen forblive en illusion. Socialdemokratiet byggede derfor »... ikke på håb og løfter, men på den økonomiske udviklings uafvendelige nødvendighed. $«{ }^{15}$ At de kun ville gøre, hvad de troede at være tvunget til at gøre, dét udgjorde på sælsom vis deres selvbevidsthed. »Utopiske forestillinger « var ilde set. Man var videnskabelig, d.v.s. man kunne hævde, at modstanderen burde have forstået, at »... skabelsen af en ny samfundsform i stedet for den bestående ... ikke mere bare var noget $\varnothing$ nskværdigt, (men) ... noget uundgåeligt. «16 Ifølge Kautsky stod det hverken i socialdemokratiets magt at skabe denne revolution eller i dets modstanderes magt at forhindre den. ${ }^{17}$

12. Samme sted s. 106 .

13. Gerhart von Schultze-Gävernitz: Der Grossbetrieb, ein wirtschaftlicher und socialer Fortschritt. Ein Studie auf dem Gebiete der Baumwollindustrie. Leipzig 1892.

14. Eduard Bernstein: Technich-ökonomicher und sozialökonomicher Fortschritt, i: Die Neue Zeit Jg. 11, brd. 1, Stuttgart 1893, s. 785.

15. Kautsky: Das Erfurter Programm, op. cit. s. 131.

16. Samme sted s. 136.

17. Jvf. Karl Kautsky: Ein sozialdemokratischer Katechismus, i: Die Neue Zeit, årg. 12, bind 1, Stuttgart 1894, s. 368 f. 


\section{II}

Den videnskabelige begrundelse for denne forestilling om det borgerlige samfunds transformation blev givet med den trinitariske revolutionsformel fra kapitel 24 i »Kapitalens « 1. bind. Sammenbrudsteorien kunne bevise, at de kapitalistiske produktionsforhold ved et givet punkt i udviklingen måtte blive en spændetrøje for produktivkræfterne, og at de derfor uundgåeligt måtte sprænges. En ny strukturering af det samfundsmæssige totalarbejde og en ny sammenfatning af de $\varnothing$ konomiske handlinger ville etablere sig, uanset om menneskene ville det eller ej. Dette bevis for en ny samfundsordens objektive nødvendighed kunne også føres ved hjælp af elendigg $\varnothing$ relsesteorien. Thi ifølge denne teori tvinges arbejderne af den stadigt tiltagende elendighed til at revolutionere det borgerlige system og indføre en ny samfundsorden, $\gg \ldots$ hvis de ikke aldeles vil forgå « $(\text { Kautsky })^{18}$, med andre ord $\gg .$. under truslen om undergang « (Engels $)^{19}$. Og endnu en vigtig tese begrundes ved elendigg ørelsesteorien: Den såkaldte arbejdereksklusivitetstese. Antagelsen går her ud på, at en revolution af den kapitalistiske vareproduktion ene og alene vil kunne gennemføres af proletariatet. Denne påstand kan kun begrundes gennem en teori om den absolutte elendiggørelse. Ingen andre af de argumenter, der stammer fra analysen af det borgerlige samfunds $\varnothing$ konomiske tvangssammenhænge, vil kunne bevise, at en eller anden socialøkonomisk defineret gruppe ikke blot er i stand til, men også vil blive tvunget til at vælte den kapitalistiske produktionsmåde overende. Uden elendiggørelsesteorien kan der ikke i streng objektivistisk forstand gives en begrundelse for tesen om, at det kun er arbejderklassen, der kan lade dødsklokkerne lyde over den borgerlige samfundsorden, og at den også vil blive tvunget til at gøre det.

Socialismetesen begrunder, at den nye samfundsformation, der følger efter den proletariske revolution, vil være socialismen. Denne begrundelse er imidlertid ikke et årsagsbevis, thi produktionsmidlernes fortsatte centralisering og arbejdets samfundsmæssiggørelse under kapitalismen kan ikke andet end sandsynliggøre, at der på et sådant grundlag kan opstå en ny samfundsorden, hvor menneskets magt over mennesket er fraværende. Imidlertid formidles en sikker viden om det efterkapitalistiske samfunds form gennem sammenkoblingen af denne tese og de ovennævnte teorier om elendiggørelse og sammenbrud, idet de som konsekvenser af samfundsmæssige tvangssammenhænge har

18. Kautsky: Das Erfurter Programm, op. cit. s. $136 \mathrm{f}$.

19. F. Engels: Herrn Eugen Dürings Umwälzung der Wissenschaft (»Anti-Düring«), MEW 20, s. 261. 
en quasi-naturvidenskabelig kausalitet klæbende til sig. På denne måde er det ikke blot revolutionen, men også dens proletariske form og dens socialistiske mål, der er objektivt determineret.

\section{III}

Den kausale logik, som den socialdemokratiske revolutionsteori gør krav på, lader sig begrunde ud fra Marx. Sammenfatningen af det samfundsmæssige totalarbejde etablerer sig som tvangssammenhæng bag om ryggen på menneskene under den kapitalistiske vareproduktion, og udfolder således en selvregulerende dynamik, som menneskenes handlinger er bundet til. Man kan derfor antage, at den kapitalistiske vareproduktions udviklingslove virker som naturlove. Der dukker imidlertid problemer op, når man vil begrunde, at Marx selv har forfægtet en sådan revolutionsteori. Det drejer sig her ikke om sammenbrudsteorien eller socialismetesen. I »Kapitalen « kan man finde argumenter, der støtter socialismetesen ${ }^{20}$, og ud fra et »sted « $\mathrm{i} »$ Grundrisse « kan man finde belæg for, at Marx i det store og hele var overbevist om, at det kapitalistiske system fra et bestemt punkt ikke længere ville være i stand til at reproducere sig ved egen kraft. ${ }^{21}$ Derimod - og det er det afgørende - kan man ikke opdrive nogen argumenter i den udfoldede kritik af den politiske økonomi, der viser, at Marx var tilhænger af en elendiggørelsesteori. Elendiggørelsesteorien forfægter Marx kun i sine tidlige værker, d.v.s. i økonomikritiske tekster, hvor det er tydeligt, at teoridannelsen er afhængighed af hans klassiske engelske forgængere. I »Kapitalen« er der derimod ikke længere tale om nogen elendiggørelsesteori.

Elendiggørelsesteoriens centrale betydning for en objektivistisk revolutionsopfattelse fremgår imidlertid allerede deraf, at ortodokse marxister altid har indført en udførlig beskrivelse af absolut og relativ elendiggørlse, når de i deres kompendier over og populære fremstillinger af den Marx'ske teori behandler den kapitalistiske akkumulations almene love. ${ }^{22}$ Grunden hertil er, at

20. Jvf. Marx: Das Kapital, brd. I, MEW 23, s. 526, dansk udgave s. 715. Og: Der Bürgerkrieg in Frankreich. Adresse des Generalrats der Internationalen Arbeiterassoziation. MEW 17, s. 343.

21. K. Marx: Grundrisse der Kritik der politischen Ökonomie (Rohentwurf), Berlin/DDR 1953, s. 636, dansk udgave s. 585 .

22. Jvf. omtalte kapitler i: Grundlagen des Marxismus-Leninismus. Lehrbuch. Efter den 2. russiske udgave. Berlin/DDR 1963, s. 280 ff; Akademie der Wissenschaften der USSR. Institut für Ökonomie. Lehrbuch. Efter den 4. russiske udgave. Berlin/DDR 1964, s. 146-151; 
opgiver man elendigg ørelsesteorien, så falder også tesen om revolutionens proletariske form som afslutning på den kapitalistiske epoke til jorden. Opgives elendigg ørelsesteorien, kan man kun bevise, at den historiske samfundsformation kapitalisme efter sin opståen og første opsving gennemløber en blomstringsperiode og nedgang for til sidst at ophøre med at kunne fungere som et selvregulerende og selvreproducerende system. Og denne opfattelse kan begrundes med Marx' kapitalanalyse. Derimod findes der i Marx' hovedværk intet holdepunkt for at drage slutninger om en tilsvarende »kausalitet « med hensyn til revolutionens form. Den eneste tese, man kan begrunde, er, at en ny form for samfundsmæssig sammenfatning er nødvendig. Der kan ikke i »Kapitalen « opledes noget grundlag for at bestemme hvilken gruppe, der vil agere samfundsforandrende i kapitalismens sluttelige krise, hvis det overhovedet vil være en socioøkonomisk defineret gruppe.

Når argumentet for, at proletariatet udgør den bærende gruppe i revolutionen, falder bort, så forsvinder også den begrundede overbevisning om, at den samfundsorden, der afløser kapitalismen, nødvendigvis måtte være socialismen. Thi med overvindelsen af den kapitalistiske vareproduktion og dermed en samfundsmæssig tvangssammenhæng, der reproducerer sig med objektiv nødvendighed og i hvilken menneskenes handlinger er fastholdt enten de vil det eller ej, frigøres subjektiviteten forstået som bestemmende kraft for samfundets struktur og sammenfatning. Hvilket ansigt den efterkapitalistiske samfundsorden får, afhænger derfor af den samfundsgruppe, som har spillet den dominerende rolle i revolutionen.

Når den objektivistiske revolutionsopfattelse ikke kan sætte lighedstegn mellem subjektet i den samfundsmæssige omvæltning og arbejderklassen uden at inddrage elendiggørelsesteorien, så er det både umuligt at begrunde tesen om at den kapitalistiske epoke afsluttes med en proletarisk revolution, og at socialismen afløser denne epoke. Jeg drager heraf følgende slutning: Forstår man i overensstemmelse med Marx »Kapitalen « som en teoretisk begrundelse for kommunismen, kan man ikke samtidig have den opfattelse, at Marx objektivt har udledt den proletariske revolution og overgangen til socialismen af analysen af den kapitalistiske vareproduktions bevægelseslove.

særlig interessant er de »læretrin«, som Schellenberg beskriver i det samme grundkursus h.h.v. til DDR (1967) og BRD (1969). Jvf. Schellenberg: Grundkursus zum »Kapital«. Berlin/DDR 1967 h.h.v.: Wie lese ich »Das Kapital«. Frankfurt/M. 1969. 


\section{IV}

Hvor lidt den objektivistiske opfattelse af den proletariske revolution har med Marx’ teori at gøre, bliver efter min mening klart, når man undersøger dens strukturelle implikationer og konsekvenser.

I første omgang kan man vise, at det revolutionære element i denne teori ikke skyldes tankens opg ør med sin genstand. Det er tvært imod de samfundsmæssige forhold, der sætter den revolutionære konsekvens i tanken. Det er således ikke kritikkens form, men resultatet af den kapitalistiske vareproduktion, der bestemmer tankens retning og mål. Teorien om den proletariske revolution er en konsekvens af de materielle forhold, d.v.s. det borgerlige samfunds selvregulerende dynamik, som fører til proletariatets elendiggørelse og den kapitalistiske produktions sammenbrud. Revolutionære tanker afspejler blot revolutionære forhold. Teoretisk kritik af den kapitalistiske vareproduktion er kun en refleks af denne samfundsformations selvkritik. ${ }^{23}$

Forholdet mellem tænkningen og dens genstand slår ned i den form, hvori de videnskabelige resultater fremstilles: Analysen af forholdet og dets konsekvenser bliver til et system af udsagn om en objektverden, i hvilken en bestemt forandring (revolution) beskrives som en nødvendig konsekvens af en kvasinaturlovmæssig udvikling (sammenbrud, elendiggørelse) og ovenikøbet på en måde, der svarer til en logisk følgeslutning, hvis a så b. Her drejer det sig slet ikke om tænkende og handlende mennesker.

I den revolutionsopfattelse, der her er på tale, forbliver den »kritiske« tænknings motivation og karakter bundet til realobjektets logik. Den afleder derfor også de revolutionære handlingers motivation og karakter af den forefundne realitet, som moment ved de materielle forhold og ikke som kvaliteter eller evner ved subjektet. Det revolutionære subjekt forbliver indesluttet i den historiske tvangssammenhæng selv under den mest »skabende akt« historien kender; den grundlæggende forandring af de samfundsmæssige forhold.

I denne revolutionsopfattelse udgår den revolutionære handlings nødvendighed altså ikke fra det revolutionære subjekt selv, men fra den udviklingsretning, som de materielle forhold tager. Forholdenes tvang dikterer proletariatet dets historiske opgave. De sammenhænge i hvilke menneskene lever, men ikke bevidst regulerer, og som de derfor er afhængige af, udgør den objektive begrundelse for deres handlinger og virker igennem disse tilbage på de materielle

23. Man kan hos Joachim Bischoff: Gesellschaftliche Arbeit als Systembegriff. Über wissenschaftliche Dialektik. Berlin 1973, s. 72 få genopfrisket, at der gives sådanne beskedne vurderinger af åndelige evner, ifølge hvilke »tankens bevægelser ... kun genspejler udviklingen i naturens og menneskenes historiske verden. 
livsbetingelser. Arbejderklassens indvarslede selvbestemmelse er altså en bestemmelse, der er givet med de samfundsmæssige forhold, dens egen frigørelse er en frigørelse påtvunget af objektive udviklingslove, dens selvrealisering er virkeliggørelsen af mål, der er indprentet som historisk nødvendigt resultat i den kapitalistiske vareproduktions udvikling.

Den iboende forrang, som den samfundsmæssige væren og dens udviklingslove her har over for såvel den kritiske tænkning som den revolutionære handling, betyder, at der ikke består nogen formidling mellem tænken og handlen overhovedet. Da der hverken i den kritiske tænkning eller i den revolutionære handling sætter sig andet igennem end de materielle forholds logik, er det ikke nødvendigt for den kritiske tænkning at bedømme sig i forhold til den revolutionære handlen for at udforme en teori om revolutionen. Ej heller er det nødvendigt for den revolutionære praksis at forholde sig til den kritiske teori for at gennemføre revolutionen. Hvilken funktion skulle også en bevidsthed, der er skolet i det teoretiske arbejdes resultater, kunne have, når revolutionen angår fuldbyrdelsen af en nødvendig opgave stillet af historiens logik og ikke mål, som mennesket har sat sig.

Det har imidlertid konsekvenser for denne revolutions praktiske gennemførelse, at kritisk teori og revolutionær praksis er adskildte i denne teoretiske opfattelse af den proletariske revolution. Teorien kommer til at dominere over praksis. Teorien kræver monopol på at fortolke de samfundsmæssige forhold. Den udleder de revolutionære handlingers mål af analysen af den borgerlige samfundsorden. Den bestemmer og begrunder revolutionens subjekt udfra objektive strukturelle forhold, den udarbejder den nødvendige kampstrategi og organisationsform for den revolutionære praksis med videnskabelige metoder. Teorien formulerer altså objektive opgaver for det revolutionære subjekt. Hermed er det teoretisk skolede hoveds formynderskab over handlingen signaleret: Ønsker det revolutionære subjekt at afklare sig med hensyn til sine mål, kan det med sikkerhed vente at blive kritiseret for idealisme, utopisme og voluntarisme fra teoriens side. Ønsker proletariatet at skærpe de »objektive « modsætninger i borgerskabets $\emptyset$ konomiske, sociale og politiske herredømme gennem politiske aktioner, så kan det med henvisning til de mulige fejltagelser, vildfarelser, overflødige ofre og nyttesløs spild af tid og energi regne med at blive foreholdt hvor ubehagelige konsekvenser, der følger af et vilkårligt indgreb i kapitalens udviklingslove. Ønsker arbejderne at gøre sig fri i praksis, vil teorien skræmme dem med henvisning til, at alt kan tabes, hvis der handles overilet. Også når det drejer sig om de efterkapitalistiske forhold har teorien sørget for, at den revolutionære fantasi ikke får vinger.

I betragtning af den kritiske teoris dominans over den revolutionære praksis i den objektivistiske revolutionsopfattelse, er det ikke tilfældigt, at der i 
den ortodokse marxisme har udviklet sig et teoriens herredømme (d.v.s. de intellektuelles) over praksis (d.v.s. de arbejdende masser). Tesen om indpodet klassebevidsthed, d.v.s. tesen om proletariatets manglende revolutionære modenhed og dets behov for de intellektuelles opdragelse, der blev formuleret af Kautsky i $1902^{24}$ og senere overtaget af Lenin ${ }^{25}$ var teoretisk anlagt i den objektivistiske revolutionsopfattelse, uanset hvilken rod disse fænomener så måtte have i samfundet.

\section{V}

Denne revolutionsopfattelses mest iøjnefaldende træk er den dominerende rolle, som de materielle forhold og deres udviklingslove tildeles. Den kritiske teori om disse forhold (elendigørelsesteori, sammenbrudsteori), eller sagt på en anden måde kritikken af disse forhold skyldes ikke tænkningens opg $\varnothing$ r med dem, kritikken er omvendt forholdenes selvkritik formidlet over tænkningen. Tilsvarende skyldes den revolutionære omvæltning af disse forhold, d.v.s. den praktiske kritik af dem, ikke menneskenes opgør med det system, de lever i, tvært imod er den systemets praktiske selvkritik (elendiggørelse, sammenbrud, revolution) formidlet over det revolutionære parti.

Det er imidlertid præcis denne teoris relatering til de kapitalistiske forholds reale udvikling, denne abstraktion fra tænkende og handlende mennesker, der inden for teoriens rammer gør socialismen »videnskabelig «. »For at gøre socialismen videnskabelig måtte den først gives et realt grundlag «, som Engels skriver i »Anti-Dürin « ${ }^{26}$. Socialdemokratiet skulle holde sig til de »håndgribelige, materielle kendsgerninger ${ }^{27}$ og smide alle forestillinger om ret og uret, ønsker, forhåbninger og utopier over bord. Marx havde aldrig funderet sine kommunistiske krav på »moralske følelser«; men på »det nødvendige og for vore øjne dagligt voksende sammenbrud i den kapitalistiske produktionsmåde $\ll^{28}$. Og hvad angår elendiggørelsen, så

24. Jvf. Kautsky: Die Revision des Programms der Sozialdemokratie in Oesterreich, i: Die Neue Zeit, årg. 20, bind 1, Stutgart 1902, s. 79 f.

25. Jvf. Lenin: Was tun?, i: Werke bind 5, Berlin/DDR 1959 s. 385 f.

26. Engels: »Anti-Düring «, MEW 20, s. 19.

27. Samme sted s. 147.

28. Engels: Vorwort (til første tyske udgave af Marx »Das Elend der Philosophie«), MEW 21, s. 178. 
vælger Engels med henblik på at fremhæve karakteren af den materielle nødvendighed, der driver arbejderklassen til handling, en vending, der fra Marx' side er brugt som sprogligt udtryk for at fremstille akkumulationen som kapitalens tvangslov: »Idet den kapitalistiske produktionsmåde efterhånden forvandler befolkningens store flertal til proletarer, frembringer den den magt, som under truslen om undergang er tvunget til at gennemføre denne omvæltning. ${ }^{29}$ For den objektivistiske revolutionsteori gælder det altså, at beviset for kommunismen udfra arbejderklassens elendighed og den kapitalistiske produktions sammenbrud har samme sikkerhed og ophøjethed som et matematisk bevis. Allerede den unge Engles skrev: »Med samme sikkerhed som vi kan udvikle en ny formel på givne matematiske aksiomer, med samme sikkerhed kan vi ud fra de bestående økonomiske forhold og nationaløkonomiens principper slutte os til en kommende social revolution. « ${ }^{30}$ Med det »reale grundlag «, de »håndgribelige, materielle kendsgerninger« troede de socialdemokratiske »verdensforbedrere« at have tiltusket sig dét »sikre historiens befordringsmiddel «, som Rosa Luxemburg mente var nødvendigt, hvis man skulle »bringe andet end et blåt $\varnothing j e$ hjem « fra det vilde ridt mod »store verdensreformer«. De var ikke opmærksomme på, at de dermed havde bygget revolutionsteorien på en ganske bestemt vurdering af den kapitalistiske udviklings fremtidige forløb; et grundlag som kunne modbevises af den faktiske udvikling. Derfor gav socialdemokratiet de borgerlige Marx- og marxismekritikere argumenter på hånden, der nemt kunne returneres som en $\emptyset$ refigen. De akademiske modstandere af den marx'ske arv lod ikke denne chance ligge unyttet. Den liberale fraktions katetersocialister og manchesterskolens tilhængere var ikke så dumme, som Engels med sin bidende spot alt for skødesløst troede om enhver borgerlig kritiker af »vor forfatter $\aleph^{31}$. De rettede deres kritik mod det svageste led i den socialdemokratiske revolutionsteoris begrundelsessammenhæng, nemlig elendiggørelsesteorien, som siden slutningen af det 19. årh. stadigt tydeligere blev modsagt af den reale udviklings kendsgerninger. Som den første rykkede Rosa Luxemburg's professor Julius Wolf i felten og stak statistiske oplysninger fra England og kongeriget Sachen i synet på elendiggørelsesteoretikerne. ${ }^{32}$ Lujo Brentano udviklede med henblik på en analyse af »arbejderforeningernes « (Arbeitergilden) фkonomiske konsekvenser en særlig »lære

29. Engels: »Anti-Düring«, MEW 20, s. 261.

30. Engels: Zwei Reden in Elberfeld, II, MEW 2, s. 555.

31. Engels til Nikolai Franzewitsch Danielson i Petersborg d. 5. januar 1888, MEW 37, s. 9.

32. Jvf. Julius Wolf: Sozialismus und kapitalistische Gesellschaftsordnung. Kritische Würdigung beider als Grundlegung einer Sozialpolitik. Stutgart 1892. 
om lønstigninger «. ${ }^{33}$ Gehart von Schultze-Gävernitz gik videre. Han opstillede som tidligere nævnt en empirisk underbygget tese, der gik ud på, at den kapitalistiske produktions udvikling fra småvirksomheder til storforetagener automatisk ville medføre en forbedring af arbejderklassens sociale situation $^{34}$. Georg Adler formulerede den skarpeste kritik af det teoretiske grundlag for den socialdemokratiske teori. ${ }^{35}$ Hans indvendinger foregreb i den grad Bernstein's senere kritik af den ortodokse teori, at revisionismens marxistiske kritikere så sig nødsaget til at affeje Bernstein's kritik som et resultat af borgerligt påvirket tankegang uden at gøre sig den anstrengelse at underkaste deres eget teoretiske standpunkt en kritisk efterprøvning.

I første omgang optrådte Bernstein imidlertid som elendiggørelsesteoriens forsvarer over for dens akademiske kritikere, idet han indtil midten af 90'erne fuldt og helt stod på den ortodokse positions standpunkt. Udgangspunktet for hans udvikling mod revisionismen blev, ${ }^{36}$ at han kun kort tid efter mistede troen på sine egne beviser for den proletariske revolutions grundlæggende teori. ${ }^{37}$

Dermed begyndte imidlertid først historien om elendiggørelsesteoriens ulykkelige redningsfors $\varnothing$ g. Den næste, der rykkede ud til forsvar for dette uundværlige »kritikkens våben « var Kautsky, thi uden denne teori kunne det ikke mere fastholdes, at den socialistiske revolution var historiens dom over den borgerlige vareproduktion, eller at proletariatet med nødvendighed var dommens eksekutor. Hans relativering af elendiggørelsesteorien til en teori om relativ elendigg $\varnothing r e l s \mathrm{~s}^{38}$ reddede ganske vist elendigg $\varnothing$ relsesteorien fra en alt for tydelig modsætning til de socioøkonomiske realiteter; imidlertid var det ikke længere muligt for ham at rekonstruere den objektivistiske begrundelse for den proletariske revolution. Da relativ elendiggørelse er fuldt forenelig med en stigende realløn, så begrunder teorien herom ikke mere

33. Jvf. Lujo Brentano: Die Lehre von Lohnsteigungen mit besonderer Rücksicht auf die englischen Wirtschaftslehrer, i: Jahrbücher für Nationalökonomie und Statistik bind 16, Jena 1971; h.h.v.: Zur Lehre von den Lohnsteigerungen, i: Zeitschrift für die gesamten Staatswissenschaften, bind 32, Tübingen 1876; h.h.v. Die Arbeitergilden der Gegenwart, Leipzig 1871.

34. Jvf. fodnote 13 .

35. Georg Adler: Die Grundlagen der Karl Marxschen Kritik der bestehenden Volkswirtschaft. Kritische und ökonomisch-literarische Studien, Tübingen 1878.

36. Jvf. Christian Gneuss: Um den Einklang von Theorie und Praxis. Eduard Bernstein und der Revisionismus, i: Marxismusstudien. Anden række. Iring Fetscher ed .. Tübingen 1957, s. 210 .

37. Jvf. Eduard Bernstein: Entwicklungsgang eines Sozialisten, i: Felix Meiner ed.: Die Volkswirtschaftslehre der Gegenwart ind Selbstdarstellungen. Leipzig 1924, s. 24.

38. Jvf. Kautsky: Bernstein und das sozialdemokratische Programm. Eine Antikritik. Stutgart 1899, s. $114 \mathrm{ff}$. 
dén objektive nødvendighed, der skulle tvinge de undertrykte til systemoverskridende handling. Her betegner elendiggørelse nemlig ikke noget, der som sådant kan fornemmes subjektivt; men tvært imod noget, der kan fremlægges som resultat af komplicerede og ofte tvivlsomme statistiske udregninger.

Efter marxismens første krise var de »socialdemokratiske modapologeter « efter Adorno's mening hverken i stand til at opfatte »den hån, som udtrykket relativ elendiggørelse råbte mod deres møje, $\ll^{39}$ eller lade sig forvirre af de statistiske oplysningers tydelige tale, da de igen inddrog den absolutte elendiggørelsesteori i den socialistiske agitations og propagandas arsenal. I en artikel i Prawda fra 1912 hævdede Lenin med henvisning til statistiske oplysninger om forholdene i Tyskland, at arbejdernes elendiggørelse i de kapitalistiske samfund ikke kun var relativ, men også absolut. ${ }^{40}$ Under Stalin blev elendiggørelsesteorien optaget blandt de »åndelige våben«, som skulle »opfylde det revolutionære legitimationsbehov i et efterrevolutionært samfund $\ll{ }^{41}$ Absolut og relativ elendighed for arbejderne under kapitalismen; absolut og relativ forbedring af de arbejdendes situation under socialismen $;{ }^{42}$ med denne besværgelsesformular, som trådte i de ærværdige sociale »lovmæssigheders « sted, skulle sovjetbefolkningen holdes skadesløs for den utroligt strenge konsumbegrænsning i nøgleindustriernes opbygningsfase.

Helt til 1950'erne fastholdt den ortodokse teori den absolutte elendiggørelsen ${ }^{43}$, og den relative elendigg ørelse indgår endnu som fast dogme i den selvbestaltede marxistiske arv. Sammenbrudsteorien undergik en tilsvarende skæbne, efterhånden som den faktiske udvikling tydeligere og tydeligere viste, at det kapitalistiske systems overlevelsesduelighed var betydeligt bedre, end dets revolutionære kritikere håbede. Man diskuterede faseteoretiske opfattelser af det »nye«, »højeste « og angiveligt »sidste « stadium i kapitalismen. Det forunderlige er blot, at de ortodokse tilhængere af den objektivistiske revolutionsteori ikke forfaldt til en relativering af sammenbrudsteorien, til en teori om det relative sammenbrud.

Man kan altså sige, at socialismens udvikling fra utopi til videnskab sådan som Friderich Engels opfattede den overhovedet ikke har givet den tyske arbejderbevægelses kommunistiske fordring fast grund under fødderne med sin

39. T.W. Adorno: Reflexionen zur Klassentheorie, i: Gesammelte Schriften, bind 8. Frankfurt/M. s. 384.

40. Lenin: Die Verelendung in der kapitalistische Gesellschaft, i: Werke bind 18, s. 428.

41. Oskar Negt: Einleitung in A. Deborin, N. Bucharin: Kontroversen über dialektischen und mechanistishen Materialismus. Frankfurt/M 1969, s. 15.

42. Stalin: Zu den Ergebnissen der Arbeiten der XIV. Konferenz der KPR(B), i: Werke bind 7, s. 83.

43. Jvf. fodnote 22 . 
begrundelse i de »håndgribelige, materielle kendsgerninger « ${ }^{44}$ og den kapitalistiske produktionsmådes udviklingstendenser. Den erklærede modsætning til den utopiske socialisme har i denne form vist sig at være problematisk, ikke blot for teorien men også for praksis. Kautsky's deterministiske marxtolkning førte ikke alene til revolutionære attentisme ${ }^{45} \mathrm{i}$ teoretisk forstand, sådan at forstå, at man ikke gjorde sig nogen som helst anstrengelse for at forstå, hvad bevægelsens medlemmer ville. Den betød også, at man ingen praktiske planer havde for erobringen og anvendelsen af magten i staten ${ }^{46}$ Den russiske arbejderbevægelse demonstrerer, at den revolutionære attentisme var bagsiden af den objektivistiske brug af Marx' teori. Her vidste partiet ganske vist, hvad det ville, og det skortede da heller ikke på praktiske planer. Blot var det de partiintellektuelle, der havde monopol på denne viden og en hertil svarende opdragelsesfunktion over for den »simple« arbejder, som ifølge teorien ikke var i stand til at gennemføre andet end en trade-unionistisk kritik af de borgerlige produktions- og livsbetingelser. Og dette opdragelsesarbejde viste sig snart at være, hvad den stadig er - et sisyphosarbejde.

\section{VI}

Marx delte tilsyneladende også denne frontale modstilling af den videnskabelige og den utopiske socialisme som Engels fremhævede og som den socialdemokratiske marxisme videregav. Havde han måske ikke sammen med Engels formuleret det i den »Tyske Ideologi«: »Kommunismen er for os ikke en tilstand som skal frembringes, et ideal som virkeligheden må rette sig efter. Kommunisme betegner vi den virkelige bevægelse som ophæver den nuværende tilstand. Betingelserne for denne bevægelse giver sig af den nu eksisterende forudsætning. «" Andre »steder«, som også går på modsætningen mellem Marx' og Engels' opfattelse og de store utopisters, lyder på samme måde. Læseren af de blå bind bliver først overrasket i bind 18. I »Konspekt von Bakunins 'Staatslichkeit und Anarchie' »bemærkede Marx om begrebet »videnskabelig socialisme«: »... er kun blevet brugt i modsætning til den utopiske socialisme,

44. Engels: »Anti-Düring«, MEW 20, s. 147.

45. Dieter Groth: Negative Integration und revolutionäre Attentismus. Die deutsche Sozialdemokratie am Vorarbend des Erstens Weltkrieges. Frankfurt/M-Berlin-Wien 1974.

46. Jvf. Helga Grebing: Geschichte der deutschen Arbeiterbewegung. Ein Überblick. 2. opl. München 1966, s. 115.

47. Karl Marx/Friedrich Engels: Die deutsche Ideologie, MEW 3, s. 35. 
som vil påhæfte folket nyt hjernespind i stedet for at begrænse videnskaben til erkendelsen af den sociale bevægelse, som folket selv har skabt ...«48

Marx havde åbenbart alligevel andre indvendinger imod den utopiske socialisme end Engels. Det drejede sig for ham om at kritisere den utopiske målsætning og at henvise til at arbejderbevægelsen må holde sig til de materielle kendsgerninger i den kapitalistiske udvikling hvis den vil have succes. Socialismens videnskabelighed må altså ifølge Marx dreje sig om andre momenter end dem som Engels og efter ham marxismen forbandt med den. Marx kritiserer på dette sted at den utopiske socialisme vil påhæfte folket nyt hjernespind. Det modsatte af denne fremgangsmåde - og dét må ifølge Marx være den videnskabelige socialismes særkende - beskrev han med følgende formulering: »erkendelse af den sociale bevægelse, som folket selv har skabt.« Marx vender sig altså ikke mod det utopiske, men mod det doktrinære element i de utopiske socialisters teorier. Disse udvikler målene i deres egne hoveder og pådutter folket dem. Det er imod dette at Marx retter sin kritik.

I modsætning dertil arbejder den »videnskabelige socialisme « med erkendelsen af den sociale bevægelse som folket selv har skabt. Den tager altså dennes mål op og analyserer denne bevægelses samfundsmæssige karakter. Denne fortolkning stemmer også overens med den anklage, som Marx og Engels formulerede sammen i »Det kommunistiske manifest «: de utopiske socialister »ser på proletariatets side ingen historisk selvvirksomhed, ingen særlig politisk bevægelse « ${ }^{49}$. En sådan forståelse af det, som hos Marx hedder »videnskabelig socialisme «, kaster et nyt lys over emnet revolutionær teori. Den »virkelige bevægelse som ophæver den nuværende tilstand $\aleph^{50}$, som teorien må forholde sig til, betyder ikke udviklingen af de kapitalistiske produktionsforhold, men den sociale bevægelse, d.v.s. oppositionen mod de borgerlige for-hold, arbejdernes systemkritiske praksis.

Først på baggrund af disse overvejelser opløses mærkværdigheden i det berømte »utopi-sted « fra »Filosofiens elendighed « hvor det om den revolutionære teoris opgave hedder: »Men i samme grad, som historien skrider frem, behøver de (socialisterne, A.M.) ikke længere at søge videnskaben i deres hoveder; de behøver kun at gøre regnskab for det, som udspiller sig for deres $\varnothing j n e$, og gøre sig til organ for det. $\ll{ }^{51}$ Hvis teoriens genstand, d.v.s. det som udspiller sig for teoretikernes $\varnothing j n e$ og som det er deres opgave at levere analysen af, skal være udviklingen af den kapitalistiske vareproduktion, så bliver det uforståeligt at den revolutionære teori skal gøre sig til organ for denne genstand. Menings-

48. Karl Marx: Konspekt von Bakunins »Staatlichkeit und Anarchie«, MEW 18, s. 636.

49. Karl Marx/Friedrich Engels: Manifest der Kommunistischen Partei, MEW 4, s. 490.

50. Marx/Engels: Die Deutsche Ideologie, MEW 3, s. 35.

51. Karl Marx: Das Elend der Philosophie, MEW 4, s. 143. 
fyldt er dette krav kun hvis genstanden, den reale bevægelse som den revolutionære teori skal forholde sig til, er proletariatets systemkritiske praksis.

Gennem disse overvejelser giver der sig et helt andet begreb om »videnskabelig socialisme«. I første omgang skal der kun fastholdes en negativ bestemmelse: det drejer sig ikke om afledningen af den proletariske revolution og den socialistiske samfundsorden ud fra analysen af bevægelseslovene i den kapitalistiske vareproduktion. Men hvad betyder »videnskabelig socialisme« positivt i Marx' forstand? »Kapital«-analysen - som dog ifølge Marx' egne ord udgør den »teoretiske begrundelse « for kommunismen og dermed ikke er andet end den »videnskabelige socialisme « - tematiserer jo det borgerlige samfunds udviklingslov! Om revolution tales der i dette værk også kun på de steder omkring den historiske tendens i den kapitalistiske akkumulation som marxister-leninisterne har trukket frem til deres revolutionsopfattelse! Hvilke andre muligheder findes der for at tyde »Kapitalen « revolutionsteoretisk end den objektivistiske måde, som er blevet diskuteret tidligere? Eller på en anden måde: hvilken revolutionsopfattelse bliver resultatet hvis man fortolker »Kapital«-analysen som »erkendelse af den sociale bevægelse som folket selv har skabt «?

\section{VII}

For at komme nærmere en positiv bestemmelse af hvordan »Kapitalen« kan fortolkes revolutionsteoretisk og hvordan den altså kan udlægges som »videnskabelig socialisme« er det efter min mening nødvendigt med en rekonstruktion af emancipationsbegrebet hos den unge Marx. Før Marx studerede dette samfunds anatomi og før proletariatet nåede ind i hans synsfelt som en mulig samfundsforandrende kraft var han i de tidlige 40'ere lige som alle unghegelianere en kritiker af den bestående europæiske samfundsorden og en forkæmper for »filosofiens virkeligg ørelse« - d.v.s. for virkeliggørelsen af de samfundsmæssige mål, som den filosofiske kritik havde udarbejdet. I kølvandet på en filosofi, som tilsyneladende ikke mere muliggjorde nogen fremskridt for erkendelsen, var denne filosofis »arvtagere « nødt til at gå ind i et refleksionsforhold til denne filosofi og den til denne svarende realitet. ${ }^{52}$ Konfronteret med en sønderdelt og indholdsløs verden og en filosofi om det absolutte (Philosophie des

52. Karl Marx: Fra bemærkningerne til dissertationen (Das Philosophisch-Werden der Welt als Weltlich-Werden der Philosophie), i Frühe Schriften. Erster Band udg. af Hans-Joachim Lieber og Peter Furth. Stuttgart 1962, s. 71/(Den ny) MEGA I.I., s. 67-68. 
Absoluten) - hvis gensidige betingethed de erkendte - kunne denne filosofis »arvtagere « kun forholde sig kritisk og dette mod begge momenter, verden og filosofi. Denne sammenhæng formulerede Marx som en »psykologisk lovmæssighed «: »dén teoretiske ånd, som er blevet fri i sig selv, (bliver) til praktisk energi og vender sig som en vilje der træder frem fra Amenthes' skyggerige mod den virkelige verden, som eksisterer uden den. « ${ }^{53}$

Udgående fra dette kritiske forhold til den eksisterende samfundsmæssige realitet og til denne realitets filosofiske system analyserer den kritiske filosof formerne for de samfundsmæssige forhold og i takt med den fremadskridende analyse af disse former udvikler han opfattelser af målet d.v.s. postulater i virkeliggørelsesfilosofien. Således analyserer Marx i »Kritik af den Hegelske statsret « adskillelsen af samfund og stat - en adskillelse af samfundsmæssige sfærer, som også river mennesket selv i stykker i statsborger og privatperson. Svarende til denne fremstilling og kritik af de samfundsmæssige forhold udvikler han målopfattelsen, den kritiske filosofis postulat. Det er kravet om »menneskenes identitet med sig selv og en identitet af menneske og art $\ll^{54}$. I »Om jødespørgsmålet« er både analysen af de samfundsmæssige forhold og også målopfattelsen udarbejdet mere konkret. Gennem den immanente kritik udvikler Marx livsformen i det borgerlige samfund, hvori materialismen og egoismen hersker og hvori det egentlige formål med det menneskelige liv, artens fællesskab, fordrejes til middel for det individuelle liv. Denne form for samfundsmæssigt liv konfronterer han med statslivets form i hvilken artslivet er mål i sig selv og det individuelle liv udelukkende udg ør dettes mulighedsbetingelse. Det postulat i den kritiske filosofi som svarer til denne kritik af de eksisterende samfundsmæssige forhold lyder: overvindelse af dualismen ved at de normer, som gælder for menneskenes forhold i statslivet, ophøjes til normer for totaliteten af alle menneskelige relationer. ${ }^{55}$

Allerede med sammenligningen af disse to skrifter kan det påvises: Postulaterne i den kritiske filosofi stemmer overens med den kritiske analyse af de samfundsmæssige forhold, men de bliver ikke afledt af den. Det som accentueres negativt $\mathrm{i}$ analysen af realiteten udgør positivt vendt motiv og sigtepunkt i den kritiske filosoferen. Og et andet moment forekommer mig vigtigt: Postulaterne i den kritiske filosofi er ligesom kritikken af de samfundsmæssige forhold ikke færdige en gang for alle, den kritiske tænknings standpunkt er ikke formuleret udtømmende og derfor ikke fixeret. Der bliver ikke opstillet

53. Sammesteds.

54. Thomas Meyer: Der Zwiespalt in der Marx'chen Emanzipationstheorie. Studie zur Rolle des proletarischen Subjekts. Kronberg Ts. 1973, s. 33.

55. Jvf. sammesteds, s. $38 \mathrm{ff}$. 
en uforanderlig målestok, som de reale samfundsmæssige forhold skal ses i forhold til. Des mere virkelighedens former indgår i analysen ændres motivet $\mathrm{i}$ den kritiske tænkning og den kritiske filosofis postulater modificeres.

Vigtigt for den tidlige Marx'ske opfattelse af filosofiens virkeliggørelse er imidlertid ikke kun tænkningens forhold til genstanden og dermed formen for den kritiske filosoferen. Hvordan filosofien skal virkeliggøres er først og fremmest et praktisk spørgsmål. Formuleringen fra den ledende artikel i nr. 179 af 'Kölnische Zeitung' om at »Filosofien står med hjernen i verden før den stiller sig med benene på jorden $\aleph^{56}$ skal her ikke kun forstås sådan, at den teoretiske opfattelse må eksitere før den kan omsættes i praksis. Vigtigere er den omstændighed, at filosofien først må indgå i menneskenes hoveder før disse kan gennemsætte den i virkelgheden. Dermed henvises der til filosofiens »praksispartner «. Denne må have en filosofisk bevidsthed, d.v.s. have tilegnet sig filosofiens resultater, for at kunne handle »à la hauteur des principes «. Den må have viljen til at virkeliggøre filosofien i stedet for egne partikulære interesser, d.v.s. den må ikke være forfalden til »hverken den himmelske eller den jordiske verdens nydelsessyge og egoisme ${ }^{57}$. Overfor et sådant revolutionært subjekt måtte den kritiske filosofi have den opgave, at initiere en bevidsthedsændring og en sublimering af viljen, d.v.s. fremskynde dets sociale bestræbelser. Det er i hvert tilfælde en opgave hvor teorien ville blive tilskrevet en ligeså dominerende rolle som i den tidligere diskuterede objektivistiske revolutionsmodel.

Denne rolle, som teorien spiller overfor praksis, ændrer sig afgørende hvis opfattelsen omkring filosofiens virkeliggørelse ikke kun udgår fra de ovenfor nævnte intellektuelle og det revolutionære subjekts moralske evner. En sådan mere udvidet emancipationsopfattelse udviklede Marx i september 1843 i et brev til Ruge. Allerede igangværende, praktisk kritik, som i sine motiver og ledetråde stemmer overens med standpunktet og målbestemmelserne i den filosofiske kritik, bliver til filosofiens anknytningspunkt. Tænkningen må knytte sin kritik an til disse »virkelige kampe og identificere sig med dem ${ }^{58}$. Filosofiens opgave er i denne praktiske emancipationsmodel så ikke længere at initiere en bevidsthedsændring og opdrage til den moralske handling, som fordrer det almene. Filosofien skal blot vise den kæmpende part »hvorfor den egentlig kæmper « ${ }^{59}$. Bevidstheden om dét anser Marx for »en sag, som den må tilegne sig også selv om den måske ikke vil $\ll^{60}$. I den praktiske emancipations-

56. Karl Marx: leitende Artikel i nr 179 af »Kölnischen Zeitung«, MEW 1, s. 97.

57. sammesteds s. 94.

58. Marx til Ruge, sept. 1843, MEW 1, s. 345.

59. sammesteds

60. sammesteds 
model forholder teorien sig altså til de praktiske kampes virkelige bevægelse. Teorien går derved ud fra »at verden allerede længe har besiddet drømmen om en sag, som den kun behøver at besidde bevidstheden om for virkeligt at besidde den $\aleph^{61}$. Teorien er så her endnu kun tilskrevet at bevirke en »reform af bevidstheden «, som består i »at man lader verden opdage sin bevidsthed, at man vækker den fra drømmen om sig selv, at man forklarer den dens egne aktioner«. Det drejer sig om »tidens selvafklaring (kritisk filosofi) om dens kampe og ønsker ${ }^{62}$.

\section{VIII}

Denne praktiske emancipationsmodel adskiller sig i alle væsentlige dimensioner fra den objektivistiske revolutionsopfattelse:

Mens tænkningen indenfor den objektivistiske opfattelse af revolutionen analyserer de bestående samfundsmæssige forhold uden forudsætninger eller erkendelsesledende interesser og således tilpasser sig deres logik, står den indenfor den praktiske emancipationsopfattelse altid i et reflektionsforhold til den samfundsmæssige orden. Samtidig med at den ikke selv kan udskilles fra denne ordning af forholdene måler tænkningen den med billedet af en bedre ordning, som den går ind for. Men dette billede stivner ikke til at være »de menneskelige forholds sande væsen « eller til et eller andet erfaringsoverskridende trancenderende princip. Med den fremadskridende analyse af de samfundsmæssige forhold undersøges, forandres og udvikles også tænkningens motiv, dens målopfattelser.

Dette forhold, som tænkningen har til sin genstand, kommer frem i fremstillingsformen for analysens resultater. I den objektivistiske revolutionsmodels sammenhæng førte den hidtidige ligegyldighed, som tænkningen indtog overfor dens erkendelsesobjekt, til udsagn med slutningsfiguren: hvis a, så b som form, d.v.s. et system af sætninger i hvilket tænkningen ikke selv tematiseres. Indenfor den praktiske emancipationsmodel antager fremstillingen af forskningsresultaterne form af immanent kritik. Den er en objektiv fremstilling og gennem fremstillingen kritik, d.v.s. en fremstilling som indeholder et kritisk standpunkt og ideen om bedre samfundsmæssige forhold. Men der er ikke tale om en adskillelse fra kritikkens genstand i form af »ideale postulater« eller

61. sammesteds, s. 346

62. sammesteds 
»metafysiske ideer « der uden videre sættes overfor de eksisterende forhold. Et sådant indtryk kan kun opstå hvis kritikeren af den Marxske teori begrænser sin bedømmelse til analysen af et enkelt skrift af Marx. Jo flere af formerne i den samfundsmæssige realitet der analyseres desto mere konkret lader kritikkens standpunkt og forestillingerne om bedre samfundsmæssige forhold sig bestemme.

Også en anden dimension i fremstillingsformen for Marx' frigørende teori må behandles. I den objektivistiske models sammenhæng udgjorde de teoretiske udsagn et lukket system af formulerede samfundsmæssige tvangssammenhænge og udviklingslove med en objektiv determineret konsekvens. Indenfor den praktiske opfattelse af den almene menneskelige frigørelse foreligger der derimod en åben fremstilling af analysen som tager hensyn til autonomien hos teoriens adressater. I den kritiske filosofi's struktur ligger kun afsløringen. Den formulerer ingen vejledninger til handling. Men den fremstiller samfundsmæssige livssammenhænge, hvorom teoretikeren kan forudsætte for det første at adressaten kritiserer dem, fordi han har modsatrettede forestillinger om et mere passende menneskeligt liv, og for det andet at han gennem bevidstheden om disse sammenhænge bevæges til at reagere mod disse forholds system på sin egen måde. Derfor er det praktiske livtag med genstanden for den kritiske filosofi - frigørelsen - det revolutionære subjekts selvbestemmelse og ikke teoriens konsekvens. Læseren ville slet ikke kunne opfatte teorien som afsløring hvis han ikke delte dens motiv og postulater. Den Marxske kritiske filosofi har altid fastholdt denne karakter af afsløring. Den begrænser sig til objektiv fremstilling, dømmer ikke resultaterne og ekspliciterer ikke konsekvenserne.

Det vigtigste moment i den praktiske emancipationsmodel er imidlertid den revolutionære praksis' autonomi. I den objektivistiske revolutionsmodel blev såvel det revolutionære subjekt som også dets historiske mission afledt af analysen af den kapitalistiske vareproduktion. Proletariatet ville, hvad enten det $\emptyset$ nsker det eller ej, blive tvunget til revolutionær handling gennem dets objektive situation indenfor denne samfundsorden, eller mere konkret gennem den voksende materielle nød. Heroverfor bestemmer menneskene selv i den praktiske opfattelse af frigørelsen om de hører til det revolutionære subjekt. Det er ikke de herskende forholds tvang der begrunder handlingens motiv, anledning og mål som en for individerne blindt virkende årsag. Det er derfor alene indenfor denne opfattelses rammer berettiget at fremlægge revolutionær handling som selvbefrielse, selvvirksomhed og selvrealisering.

Ligesom den kritiske tænkning indenfor denne model er viklet sammen med sin genstand i opgøret med den, således befinder den kritiske handling sig også i sammenstød med de bestående forhold. Gennem karakteren og ledetrådene i allerede stedfundne og eksisterende kampe demonstrerer det revolu- 
tionære subjekt for de kritiske filosoffer hvem disse må forholde sig til. Begge positioner imod den eksisterende realitet er beslægtede. Ligesom den kritiske tænkning bliver også den praktiske kamp ledet af ideer, som selv om de viser ud over det bestående dog ikke forbliver uberørt af den samfundsmæssige praksis. I konfrontationernes forl $\varnothing \mathrm{b}$ forandres forestillingerne om kampenes årsager og mål. De bliver korrigeret, bekræftet og videreudviklet på samme måde som tænkningen gennem fremadskridende opgør med formerne for de samfundsmæssige forhold unders $\varnothing$ gte sine kritiske motiver og postulater.

Dét at den kritiske handling må være af samme karakter som den kritiske tænkning er forudsætningen for den kritiske filosofis begrænsning til objektiv fremstilling af forholdene. Uden dette slægtskab ville det revolutionære subjekt ikke være i stand til at begribe teorien som afsløring og teorien ville ikke kunne opfylde den af Marx anviste funktion - at formidle en passende forståelse til de kæmpende om deres samfundsmæssige situation og om den samfundsmæssige karakter i deres motiver og mål. Teorien ville være tvunget til at gøre det, som Marxkritikere fejlagtigt antager, nemlig at dømme analysens resultater, formynderisk at drage følgeslutninger af dem for de handlende og give dem handlingsanvisninger.

Endnu et moment må tilføjes: Indenfor den objektivistiske revolutiånsmodel førte de samfundsmæssige forholds primat til at det såvel i den kritiske tænkning som i den kritiske handlen ikke er andet end logikken i de materielle forhold der sætter sig igennem. Tænkningen behøvede ikke praksis for at lave teorien om revolutionen og de handlende var ikke nødt til at tilegne sig teoriens resultater for praktisk at gennemsætte revolutionen.

Indenfor den praktiske emancipationsmodel forholder det sig anderledes: Ikke blot henviste Marx teoretikeren til at identificere sin kritik med de praktiske kampe; Marx fastholdt også overfor den kæmpende part at bevidstheden er en sag som den må tilegne sig. Thi uden bevidsthed kan de revolutionære kræfter ikke frembringe den samfundsmæssige livssammenhæng, som i modsætning til det kapitalistiske system skal være bevidst reguleret af menneskene selv. Begge, tænkning og praksis, indtager altså ikke kun beslægtede positioner, de er også afhængig af hinanden, henvist til hinanden m.h.t. gyldigheden af deres resultater; eller bedre, deres resultat: filosofiens virkeliggørelse, er ikke andet end det revolutionære subjekts virkeliggørelse af sig selv. Af den praktiske kritik af den bestående samfundsorden, som trods dens forestilling om revolutionær teori-praksis-formidling endnu er præget af den samfundsmæssigt satte adskillelse af teori og praksis, udvikler den kritiske filosofi sig til en »kritik i håndgemæng « gennem den dobbelte proces: identificering af sin kritik med den revolutionære praksis og den revolutionære praksis' (de kæmpendes) tilegnelse af denne kritik. Revolutionens hoved og hjerte er ikke læn- 
gere fordelt på to samfundsmæssige grupper, de intellektuelle og de praktiske eksekutorer af den objektivt stillede historiske opgave. I revolutionen er de sammenfaldende.

»Således gives den konsekvens, at verdens bliven filosofisk samtidig (er) en filosofiens bliven verdslig, at dens virkeligg ørelse samtidig (er) dens tab « ${ }^{63}$ I denne formulering bliver forholdet mellem revolutionær teori og revolutionær praksis indenfor den praktiske emancipationsmodel udtalt tydeligt: Verden bliver filosofisk og filosofien verdslig når de samfundsmæssige forhold bærer den med vilje og bevidsthed handlende menneskeheds åsyn. Når den revolutionære praksis har overvundet kløften mellem det, som mellemmenneskelige relationer kan være, og det, som de hidtil var har været, mister den revolutionære filosofi - menneskenes selvrealisering i anticiperet form - sit eksistensgrundlag. Den dør bort.

\section{IX}

I de tidlige skrifter af Marx kan man udpege to overfor hinanden modsatte opfattelser af den almene menneskelige frigørelse, hvis omrids jeg ovenfor har skitseret som objektivistisk revolutionsmodel og praktisk emancipationsmodel.

Allerede Bernstein opdagede en grundliggende dualisme i den Marxske teori, »som går gennem hele Marx’s monumentale værk « ${ }^{64}$. Blot opfattede han, vildledt af Engels' begreb om den »videnskabelig socialisme «, denne spaltning som en modsigelse mellem de videnskabelige, d.v.s. empirisk underbyggede, og de utopiske elementer indenfor den Marx'ske analyse af den kapitalistiske produktionsmåde. Ernst Bloch så derimod denne spaltning mere klart: Marx har fors $\varnothing \mathrm{mt}$ grundigt at reflektere forholdet »mellem 'subjektiv' vilje og 'objektiv' idé.« »Den samme mand, som bortdrev al fetichkarakter fra produktionsforløbet som troede at analysere og uddrive alle historiens irrationaliteter som rene og skære uigennemskuede, ubegrebne og derfor skæbnesvangert virkende dunkelheder ved klassesituationen, ved produktionsprocessen ... dyrkede med 'produktivkræfterne', med 'produktionsprocessen's kalkule det samme alt for konstitutive væsen, den samme panteisme, mysticisme, tildelte den den

63. Marx: Das Philosophisch-Werden der Welt ... s. 71, MEGA 1976 I.I. s. 68.

64. Eduard Bernstein: Die Voraussetzungen des Sozialismus und die Aufgaben der Sozialdemokratie, Stuttgart 1899, s. 177. 
samme nyligt anvendte, modnende og ledende magt som Hegel havde tildelt 'ideen' og Schopenhauer viljen til livet. ${ }^{65}$

Denne dualisme indenfor Marx' eget værk er årsagen til at hans skrifter bliver fortolket på to helt forskellige måder. Denne spaltning udgør altså roden til modsætningen mellem ortodoks og kritisk marxisme ${ }^{66}$. Karl Korsch formulerede i tyverne eksplicit sin position i denne sammenhæng. I diskussionen om sammenbrudsteorien vender han sig afgørende mod sådanne teorier »om en objektiv og i sit slutmål på forhånd givet økonomisk udviklingstendens, som arbejder mere med billedlige forestillinger end med entydigt bestemte videnskabelige begreber og som tilmed uundgåeligt er grundet på en utilstrækkelig induktion (erfaringserkendelse) «. Sådanne teorier forekommer ham »ikke egnet til at tilvejebringe den fulde alvor i den selvansvarlige handlen hos den proletariske klasse, som kæmper for sine egne mål ${ }^{67}$. Men Korsch knytter i sin kritiske marxisme hovedsagelig an til Marx' tidlige skrifter. Tilsvarende har ortodokse marxister, begyndende med Kautskys polemik mod Korsch ${ }^{68}$, altid spillet den sene Marx ud mod den tidlige for at underbygge den objektivistiske Marxfortolkning. Jeg tror imidlertid at der er flere argumenter end de tidlige skrifter for at Marx' sene værk, »Kapitalen «, skal fortolkes på baggrund af den praktiske emancipationsmodel.

\section{$\mathbf{X}$}

I det følgende vil jeg begrunde denne tese: Marx formulerer kun en revolutionsteoretisk objektivistisk position i sine tidlige skrifter. I »Die heilige Familie « definerer han (sammen med Engels) entydigt de materielle forholds tvang som revolutionens fremaddrivende moment: "proletariatet er ... som proletariat tvunget til at ophæve sig selv og dermed sin betingende modsætning, privatejendommen, som $\mathrm{g} \varnothing \mathrm{r}$ det til proletariat. $\ll^{69}$ Og lidt senere hedder det: »Det drejer sig ikke om, hvad disse eller hine proletar eller selv hele prole-

65. Ernst Bloch: Geist der Utopie, Berlin 1923, s. 324.

66. Jvf. hertil Thomas Meyer: Der Zwiespalt in der Marx'schen Emanzipationstheorie.

67. Karl Korsch: Über einige grundsätzliche Voraussetzungen für eine materialistische Diskussion der Krisentheorie, i: Karl Korsch, Paul Mattick, Anton Pannekoek: Zusammenbruchstheorie des Kapitalismus oder revolutionäres Subjekt. Berlin 1973, s. 97.

68. Jvf. Karl Kautsky: Rezension von Karl Korschs »Marxismus und Philosophie«, i: Die Gesellschaft bd. 1, Berlin 1924.

69. Karl Marx/Friedrich Engels: Die heilige Familie oder Kritik der kritischen Kritik, MEW 2, S. 37. 
tariatet på et givent tidspunkt forestiller sig som mål. Det drejer sig om, hvad proletariatet er og hvad det ifølge denne væren historisk vil være tvunget til at gøre. Dets mål og dets historiske aktion er håndgribeligt, uigenkaldeligt forskrevet i dets egen livssituation ligesom i hele det aktuelle borgerlige samfunds organisation. ${ }^{70} \mathrm{Mig}$ bekendt er også senere revolutionsteoretiske formuleringer med objektivistisk grundtone altid mulige at fortolke på baggrund af den praktiske emancipationsmodel.

Marx er ligeledes kun i sine tidlige skrifter fortaler for elendiggørelsesteorien den objektivistiske begrundelse for identificeringen af det revolutionære subjekt med arbejderklassen og for dennes historiske mission. Eksempelvis findes formuleringer om absolut og relativ elendiggørelse som proletariatets uundgåelige skæbne indenfor den borgerlige samfundsorden $\mathrm{i} \gg$ Pariser-manuskripterne «, i »Lønarbejde og kapital« og i fragmentet »Arbejdsløn«, dvs. i skrifter hvor hans $\varnothing$ konomikritiske forståelse endnu var afhængig af de teoretiske forestillinger hos hans forgængere Adam Smith og David Ricardo. Man finder derimod ikke længere nogen elendiggørelsesteori i de skrifter, hvor Marx's kritik af den politiske økonomi er fuldt udfoldet.

Ligeledes lader opfattelsen af en kausal sammenhæng mellem elendiggørelse og revolution sig kun belægge i de tidlige skrifter. Således skriver han (sammen med Engels) i »Die heilige Familie«: Fordi proletariatet »gennem den absolut bydende nød, der ikke mere lader sig afvise, ikke mere lader sig retfærdiggøre - og som er det praktiske udtryk for nødvendigheden - er tvunget til oprør mod denne umenneskelighed, derfor kan og må proletariatet befri sig selv. « ${ }^{71}$ Denne sammenhæng findes derimod ikke mere i »Kapitalen «. Dette kan ikke bortforklares selv med en nok så vidtløftig udlægning af begrebet »elendighed « fra 1 . binds 24 . kapitel om den kapitalistiske akkumulations historiske tendens.

I »Kapitalen« findes således ikke længere nogen argumenter som objektivt - dvs. støttet på erkendelse om tvangssammenhænge og udviklingslovmæssigheder i den borgerlige samfundsorden - kunne begrunde, at socialismen er historiens dom over den kapitalistiske vareproduktion og at proletariatet nødvendigvis er dennes eksekutor.

Mit andet argument til begrundelse af den tese, at »Kapitalen« snarere lader sig fortolke på baggrund af et praktiskt emancipationsbegreb end indenfor rammerne af en objektivistisk revolutionsmodel, relaterer sig til fremstillingsformen i analysen af det borgerlige samfunds bevægelseslove. Skulle dét ikke være ubestridt, så kunne man henvise til undertitlen på Marx's hovedværk:

70. sammesteds S. 38 .

71. sammesteds 
Hans teori er samfundskritik og ikke samfundslære. Denne teoris revolutionære karakter beror ikke på systemets objektive selvkritik i den af Hilferding forudsatte betydning, hvor den socialistiske konsekvens var resultat af de tendenser, der sætter sig igennem i det vareproducerende samfund. ${ }^{72}$ Marx’s teori giver tværtimod svar på spørgsmål, som udspringer af tænkningens kritiske opgør med de samfundsmæssige forhold og ikke af disse selv: Marx begriber de borgerlige livsbetingelser som en samfundsmæssig orden, i hvilken menneskenes relationer antager skikkelse af relationer mellem ting, i hvilke produkterne af det samfundsmæssige arbejde behersker menneskene selv. Den kapitalistiske vareproduktion bliver fremstillet som en »fordrejet « virkelighed. Og dette er en erkendelse, der bestemt ikke kan skyldes nogen genspejling af forholdene i tænkningen.

Det »fundamentalt nye element «i hans teori, ${ }^{73} »$ det bedste « ved hans bog ${ }^{74}$ er efter Marx's egen bedømmelse analysen af arbejdets dobbeltkarakter som konkret og abstrakt arbejde. Det er det »springpunkt ... hvorom forståelsen af den politiske $\varnothing$ konomi drejer sig,${ }^{75}$ og som Ricardo og med ham hele den klassiske politiske $\varnothing$ konomi har fors $\varnothing \mathrm{mt}$ at undersøge. ${ }^{76}$ Hvis man går ind for en objektivistisk revolutionsmodel, altså fremstiller det 24. kapitel fra det første bind som »Kapitalens « vigtigste revolutionsteoretiske »sted «, kan man slet ikke dele Marx's vurdering af arbejdets dobbeltkarakter som det vigtigste moment i kritikken af den politiske økonomi, det vil sige den videnskabelige begrundelse af socialismen. For til at formulere en selvkritik af det borgerlige system, dvs. en elendiggørelsesteori, en sammenbrudsteori og en socialismetese, behøvede Marx slet ikke at overvinde Ricardos videnskabelige standpunkt produktivt. Den kvantitative værdilære er tilstrækkelig for en objektivistisk revolutionsteori.

Men hvis man tilslutter sig Marx’s bedømmelse, at det samfundsmæssige arbejdes dobbeltkarakter, dvs. et specifikt praksisbegreb, udgør kernen i hans kritik af den politiske $\varnothing$ konomi, følger der en anden vurdering af den revolutionære karakter i analysen af den borgerlige samfundsorden. Denne fremgår så ikke mere af den erkendelse, at den kapitalistiske vareproduktions modsigelsesfyldte udviklingslove ved et bestemt punkt må sprænge de samfundsmæssige forhold. Den kritiske og revolutionære karakter er så ikke mere til at adskille fra selve analysens fremstilling. Den begrænser ikke sine

72. Rudolf Hilferding: Das Finanzkapital. Eine Studie über die jüngste Entwicklung des Kapitalismus. Frankfurt am Main 1968, S. 20.

73. Marx an Engels von 8. Jan. 1868, MEW 32, S. 11.

74. Marx an Engels von 24. Aug. 1867, MEW 31, S. 326.

75. Marx: Das Kapital Bd. I, MEW 23, S. 56, Dansk udg. s. 135.

76. Karl Marx: Theorien über den Mehrwert Bd. II, MEW 26.2, S. 161. 
åbenbare udtryk til hine tre sider i slutningen af »Kapitalens « første bind, den gennemsyrer hele Marx's værk. Marx's teori er »fremstilling af systemet og gennem fremstillingen kritik af dette $\ll{ }^{77}$ Den er fremstilling og kritik af det samfundsmæssige arbejde indenfor en specifik produktionsmåde, kritik af en ubevidst samfundsmæssig praksis, hvis resultater undertrykker menneskene selv.

Men at Marx's analyse i »Kapitalen« tværs gennem den objektive fremstilling er kritik, altså er en teori som - skønt den ikke eksplicit indeholder vurderinger og ikke formulerer nogen handlingsanvisninger - alligevel angriber sin genstand kritisk, er kun tilgængelig for de, der deler den kritiske tænknings motiv og ledetråd, der altså gør op med de bestående samfundsmæssige forhold på den samme måde som »Kapitalens « forfatter. Det betyder, at det for afdækningen af dens kritiske og anklagende karakter ikke er ligegyldigt, hvilken læser der tager den til sig. Kun de, som føler skrankerne for deres selvrealisering og som aner disses samfundsmæssige karakter, de der altså vil leve i en samfundsorden, hvis forhold beror på selvbestemt og bevidst samfundsorienteret handling, kun for dem åbner den revolutionære tendens i hver eneste af »Kapitalens « sætninger sig.

At Marx's hovedværk kun lader sig fortolke inden for rammerne af en praktisk emancipationsmodel, følger desuden af selve dets eksistens. At bedrive teori i det omfang Marx gjorde det ville være meningsløst, hvis man tillagde ham et revolutionsbegreb, i hvilket teori ingen funktion har, i hvilken nemlig revolutionen naturnødvendigt udspringer af samfundsordenes lovmæssigheder. Kun indenfor et praktiskt revolutionsbegreb, i hvilket den kritiske filosofi har den opgave at muliggøre en »tidens afklaring af sine kampe og ønsker « får teoretisk kritik den eminente betydning, som også Marx praktisk har tildelt den gennem sit eget livsværk. Kun i en emancipationsmodel, som foregriber samfundsmæssige forhold, der i modsætning til de borgerlige forhold afhænger af menneskenes vilje og bevidsthed, forhold i hvilke bevidstheden således er det vigtigste konstitutive moment, har teorien en funktion, der modsvarer den kritiske form, hvori Marx har arbejdet med den: nemlig udvikling af en samfundskritisk og dermed foregribende bevidsthed.

Et yderligere argument for en udlægning af »Kapitalen« på baggrund af den praktiske emancipationsmodel relaterer sig til fortolkningens konsistens. Man behøver kun kort at overveje, hvilke momenter der må falde bort - eller fortrænges til udkanten - fra den af Marx fremstillede kritik af den politiske $\emptyset$ konomi, hvis sammenbrudsteorien, elendiggørelsesteorien og socialismetesen tematisk havde været hovedsagen, for at komme til den afgørelse, at Marx

77. Marx an Lassalle vom 22. Febr. 1858, MEW 29, S. 550. 
på ingen måde tænkte på at aflede den socialistiske revolution som et nødvendigt resultat af de tendenser, der sætter sig igennem i et vareproducerende samfund. Marx's kritik er først og fremmest kritik af de samfundsmæssige former, i hvilke menneskene indenfor den kapitalistiske vareproduktion tager livtag med naturen og regulerer deres forhold til hinanden. Men denne formanalyse, hvis kritik negativt korresponderer med formerne for det foregrebne »frihedens rige «, har ingen plads i en objektivistisk revolutionsmodel. Derimod er de elementer af »Kapital«-analysen, som udgør hovedbestandelene af den objektivistiske revolutionsmodel, meget vel mulige at fortolke indenfor rammerne af den praktiske emancipationsmodel. Den af Marx fremstillede lov for den kapitalistiske akkumulation er således at begribe kritisk og anklagende som konsekvens af en samfundsmæssig orden struktureret gennem arbejdsdeling og privatarbejde. En orden i hvilken det samfundsmæssige totalarbejdes sammenfatning fremstiller sig bag om ryggen på menneskene, og som en blind tvangssammenhæng hæver sig op fra de bevidste og villede menneskelige handlinger, udvikler en egendynamik og - forudsat adskillelsen mellem producent og produktionsmiddel - munder ud i en kumulativ proces. En proces, der SOM SÅDAN og ikke kun i sine negative konsekvenser, ikke kan være villet af noget medlem af samfundet, hverken som krisebehæftet akkumulation af den samfundsmæssige rigdom på den ene side, eller som voksende udbytning, forstærket repression, tiltagende socialt og politisk herredømme på den anden side. Revolutionen, som Marx taler om i tilknytning til omtalte fremstilling af den kapitalistiske akkumulations historiske tendens, ville så ikke være at forstå som andet end den af den kapitalistiske produktion »med en naturproces' nødvendighed « frembragte »egne negation $\ll{ }^{78}$ Den er tværtimod den af Marx foregrebne reaktion hos de mennesker som har begrebet, at de »fordrejede « samfundsmæssige forhold som er fremstillet $\mathrm{i} »$ Kapitalen « er resultat af deres egen samfundsmæssige praksis.

I denne sammenhæng må det fremfor alt forklares, hvorfor Marx også i sit sene værk udelukkende satte sine revolutionære forhåbninger til proletariatet. Denne afgrænsning, sådan har jeg argumenteret ovenfor, lader sig kun begrunde gennem elendiggørelsesteorien. Men selv hvis det er sådan at Marx i »Kapitalen « forventede den afgørende aktion, der skulle afslutte »menneskehedens forhistorie « af arbejderklassen, er dette i sig selv ikke grundlag for at tillægge ham et objektivistisk revolutionsbegreb. Dettes særtræk er nemlig ikke selve identificeringen af det revolutionære subjekt med arbejderklassen, derimod deres identificering på grundlag af en kategori, der teoretisk er afledt af analysen af den kapitalsitiske vareproduktion. Også i den praktiske eman-

78. Marx: Das Kapital Bd. I, MEW 23, S. 791, Dansk udgave s. 1061 
cipationsmodel findes kriterier til identificeringen af det revolutionære subjekt. Men disse kriterier er her ikke udvundet ud af analysen af den borgerlige samfundsorden. I dette begreb er det gennem systemoppositionel praksis, der i motiver og forbilleder lader sig sammenligne med den kritiske tænkning, at det revolutionære subjekt signalerer til de kritiske filosoffer, hvem der er deres praksispartner. Når Marx således også i sit sene værk refererer til arbejderklassen som revolutionært subjekt, må det forklares gennem den kendsgerning, at denne i det 19. århundrede var den eneste samfundsmæssige gruppe, som gennem sin »virkelige bevægelse «, dvs. sine kampe mod det borgerlige samfunds bestående system, gav de kritiske filosoffer anledning til at identificere deres kritik med dens kampe. ${ }^{79}$

Ligeledes lader det sig direkte belægge, at »Kapitalen« skal ses inden for rammerne af den almene menneskelige emancipations praktiske begreb. Marx betoner også i sine senere skrifter det revolutionære subjekts autonomi. Således skriver han for eksempel i instruktionerne til de delegerede ved »Den Internationale Arbejder-association's « centralråd: »Det er den internationale arbejder-associations opgave at forene og almengøre arbejderklassens spontane bevægelser, men ikke at diktere eller påtvinge dem et eller andet doktrinært system. ${ }^{80} \mathrm{I}$ denne betydning af praktisk indøvning af selvbestemmelse og egenaktivitet skal man også forstå Marx’s forslag til »undersøgelse af den arbejdende klasses situation i alle lande, foretaget af arbejderklassen selv «. Det drejer sig om, at arbejderne selv »gennem initiativet til så stort et værk « beviser »deres evne til at tage deres skæbne i egne hænder. $\ll^{81}{ }^{2}$ At arbejderklassens emancipation må erobres af arbejderklassen selv « ${ }^{82}$ må derfor forstås i videste forstand. Ikke kapitalforholdets krisebehæftede udvikling, ikke et parti, der planlægger de revolutionære aktioners forløb, ikke en enkeltstående doktrinær, om det så var en Marx - men: »de må selv gøre det meste for deres endelige sejr derved, at de kommer til klarhed om deres klasseinteresse, indtager deres selvstændige position så snart som muligt, ikke et øjeblik lader sig forvirre omkring den uafhængige organisation af proletariatets parti af de demokratiske småborgeres hykleriske fraser. ${ }^{83}$

Spørgsmålet om hvorledes »videnskabelig socialisme« i Marx’s betydning må forstås, lader sig på grundlag af disse overvejelser sammenfatte i følgende

79. Smlg. Marx an Ruge vom Sept. 1843, MEW I, S. 345 f.

80. Karl Marx: Instruktionen für die Delegierten des Provisorischen Zentralrats zu den einzelnen Fragen, MEW 16, S. 195

81. sammesteds S. 191.

82. Karl Marx: Provisorische Statuten der Internationalen Arbeiter-Assoziation, MERW 16, S. 14.

83. Karl Marx/Friedrich Engels: Ansprache der Zentralbehörde an den Bund vom Mårz 1850, MEW 7, S. 254. 
sætninger: Hans kritiske fremstød retter sig ikke imod det utopiske, derimod mod det doktrinære moment i de utopiske socialisters teorier. Referencepunkt for revolutionær teori er derfor ikke den borgerlige vareproduktions bevægelseslove, men derimod systemoppositionelle kampe - på Marx's tid entydigt klassekampe. Deres rødder og bestræbelser må teori forklare. Den »videnskabelige socialismes« opgave som teori for den revolutionære praksis er som følge heraf ikke afledning af socialistiske mål, kampstrategier, og organisationsformer af analysen af den kapitalistiske produktions udviklingslove. Den skal heller ikke ligesom den utopiske socialisme løsgjort fra de virkelige samfundsmæssige kampe udkaste systemer og påtrykke de revolutionære kræfter disse som opgaver. Tværtimod lyder dens program: Tidens selvafklaring over rødderne til dens »fordrejede « samfundsmæssige forhold, over de samfundsmæssige motiver til dens kampe, over ønskerne som ligger til grund for disse kampe og over de mål, som de stræber efter.

\section{$\mathbf{X I}$}

Tilbage står at forklare, hvorfor Marx' hovedværk hidtil overvejende er blevet fortolket på baggrund af en objektivistisk revolutionsmodel. Selv kritiske marxister som Georg Lukacs og repræsentanter for en kritisk samfundsteori som Horkheimer og Adorno vurderer mange momenter i den marxske teori på samme måde som »Kapitalens « selvbestaltede arvtagere og deres klassemodstandere på den videnskabelige slagmark.

Jeg ser en grund til dette fænomen i den fremstillingsform, som Marx' hovedværk foreligger i. I sine ungdomsskrifter tematiserede Marx stadigvæk alle den teoretiske reflektions momenter på en sådan måde, at tankens opg ør med dens genstand blev ekspliciteret hans analyse. Thi som et led i et formuleret kritisk standpunkt og den kritiske filosofis udfoldede foregribelser fremtræder teorien om de bestående samfundsmæssige forhold uundgåeligt som kritik også selvom disse fremstilles objektivt. I »Kapitalen « begrænser Marx sig til fremstillingen af det borgerlige samfunds udviklingslove. Og dermed overlader han det til læseren selv at extrapolere det kritiske og revolutionære indhold. Selvom foregribelsen af »frihedens rige « dukker op et sted i $»$ Kapitalen ${ }^{84}$ går den tabt indenfor rammerne af et i sig selv dialektisk struktureret ${ }^{85}$ system 
over den kapitalistiske vareproduktion, der fremtræder som en konstruktion a priori ${ }^{86}$. Yderligere bidrager en objektiv fremstilling af sagen selv til den misforståelse, at dynamikken i kapitalforholdet identificeres med den revolutionære bevægelse mod systemet, som om systemets objekter skulle opfatte den revolutionære bevægelses udfoldelse som deres subjektive sag og på deres side fremdrive denne. Mange »steder $« \mathrm{i} »$ Kapitalen $«$ og $\mathrm{i}$ andre sene Marx-skrifter efterlader det indtryk, at modsigelserne i den kapitalistiske produktionsmåde på en måde i deres egenbevægelse fremkalder socialismen ${ }^{87}$, som om den oppositionelle bevidsthed (Bewusstseins des Widerspruchs) over for det bestående skulle kunne forlade sig på systemets immanente modsigelser. Det ser altså således ud, som om Marx selv i mange formuleringer ikke skulle have imødegået den fordrejning mellem subjekt og objekt i det borgerlige samfundssystem, som han ellers kritiserede så heftigt. Man må imidlertid ikke overse, at netop denne fremstillingsform, der er begrænset til den objektive analyse, og som giver anledning til objektivistiske misforståelser, på den anden side er forudsætningen for, at den foregrebne frigørelse virkelig er en frigørelse og ikke en teoretisk styret orienteret opdragelse af et videnskabeligt identificeret revolutionært subjekt og en konsekvent vejledning af dette subjekt i objektiv begrundet handlen $i$ betydningen videnskabeligt funderede mål ${ }^{87 a}$.

\section{XII}

På dette sted rejser spørgsmålet sig om, hvad »videnskabelig socialisme« kan være idag i følge den kritiske marxismes selvforståelse som en i emfatisk forstand frigørende teori. D.v.s. hvilke opgaver har idag en revolutionær teori, der går ind for en samfundsorden, hvis værdier ikke kun måles med et minimum af

86. Jvf. Marx, Das Kapital, bd. 1, s. 27. Dansk udg. 1.1., s. 105.

87. Jvf. f.x. Das Kapital bd. 3, s. 453 og 455 f. Dansk udg. 3.2, s. 569 og $572 f$.

87a. At denne objektivistiske opfattelse er en eksisterende realitet i betydningen en reel samfundsmæssig kraft med politisk betydning, kan man ikke blot udsondre af den aktuelle politik i den virkeliggjorte socialisme. I nyere publikationer om den »videnskabelige kommunisme« står der at læse, at den »marxistisk-leninistiske teori« får en »voksende betydning « i »opdragelsen af de arbejdende«, og at det derfor »kun er partiet, der forener de mest progressive repræsentanter for folket og som kender de samfundsmæssige udviklingslove og råder over en enorm praktisk erfaring i udformningen af den nye samfundsorden, ... der virkelig videnskabeligt kan lede opbygningen af kommunismen, organisere massernes aktivitet og styre den efter videnskabeligt begrundede mål.« (jvf. Autorenkollektiv: Wissenschaftlicher Kommunismus. Berlin/DDR 1972, s. 426). 
sult og undertrykkelse, men først og fremmest med den grad af selvrealisering og lykke, som det kan stille til rådighed for alle dets medlemmer.

Mit forehavende: at drage konsekvenser på baggrund af den ovenfor udviklede praktiske frigørelsesmodel kan kun være et fors $\varnothing \mathrm{g}$ på et svar, og et temmelig abstrakt fors $\emptyset$ g. Det er dermed - som al tænken, der definerer sin opgave på baggrund af en forestilling om en almen menneskelig frigørelse - et bidrag til »tidens selvafklaring om dens kampe og $\varnothing$ nsker ${ }^{88}$, her og nu desværre mere en afklaring af $\varnothing$ nsker.

Efter min mening må grundtesen i en frigørende teori og praksis efter alle historiske erfaringer, negativt formuleret, lyde således: Den oppositionelle bevidsthed overfor det kapitialistiske system af vareproducerende arbejde kan - lige så lidt som den oppositionelle praksis - ikke støtte sig på selve systemets modsigelser. En tænken såvel som en handlen, der forlader sig på logikken i en kapitalistisk »selvkritik «, er - selv hvor den ikke blot afventer systemets sammenbrud, men aktivt bidrager til det - ikke andet end revolutionær attentisme, der ikke vover at søge betingelserne for befrielse i sig selv. Den marxske kritik af det borgerlige samfund var en kritik af systemet som en totalitet. At være radikal i den marxske forstand vil sige at gå til ondets rod. Og denne rod er mennesket for hvem mennesket er det højeste væsen ${ }^{88 a}$. Det drejer sig i analysen af det kapitalstiske system af vareproducerende arbejde om kritikken af de fordrejede forhold mellem menneskene og produkterne af deres livtag (auseinandersetzung) med naturen og om kritikken af de fordrejede, tingsliggjorte forhold mellem menneskene selv. Derfor er ikke kun værdilovens negative konsekvenser, men også dens positive virkninger hjemfalden til kritik, fordi totaliteten, som et resultat af en bevidstløs samfundsmæssig handlen, subsumerer menneskene under sig, fornedrer dem, kuer dem og gør dem forargtelige ${ }^{88 b}$.

Det følger af disse overvejelser, at kapitalforholdets modsigelsesfulde udvikling ikke giver nogen baggrund for en afledning eller begrundelse af socialistiske organisationer, strategier og socialistiske målforestillinger, kort og godt for en socialistisk politik. Denne udvikler sig langt snarere af spændingsforholdet mellem tænken og handlen og den bestående realitet. Socialistiske mål har intet til fælles med samfundsmæssige forhold, som det borgerlige samfund overhovedet ville kunne udvikle af sig selv. Betingelserne for den almen menneskelige frigørelses succes og resultater er netop, at menneskene bliver i stand til at løsgøre deres bevidsthed og handlen fra

88. Jvf. Marx til Ruge, sept. 1843, MEW bd. 1, s. 346.

88a. Jvf. Marx, Zur Kritik der Hegelschen Rechtsphilosophie. Einleitung, MEW bd. 1, s. 385.

88b. Jvf. samme sted. 
afhængigheden af den bestående samfundsmæssige væren, og til at vende sig mod det bestående med bevidstheden om mulige, bedre livsbetingelser. At et mål kun kan opfyldes ved hjælp af midler og af veje, der helt og holdent er genemsyret af målets natur er en sætning, der ikke kun besidder gyldighed indenfor den Hegelske filosofi.

En socialistisk strategi må derfor være en modstrategi. Den part, der forsvarer den bestående orden, bør ikke kunne diktere modmagten formen for opgøret. Det begynder allerede i prægningen af bevidstheden: Den kendsgerning, at modstandernes bevidsthed, fordi den modsvarer den herskende orden, er klart udarbejdet, fast forankret i sine vurderingsmønstre, gennemstruktureret og derfor heller ikke til at bringe i uorden eller vildlede, bør ikke forlede socialister til af angst for allerede på det »ideologiske « område at være underlegen at opbygge en bevidsthed, der er klarere udarbejdet, mere åbenbar, sikker og endegyldig i sine vurderingsmønstre og derfor heller ikke anfægtelig eller videnskabelig angribelig. Hvis det revolutionære partis hoveder er sporet ind på en almen gyldig fortolkning af den bestående realitet og af deres opgaver, så har revolutionen af den bestående samfundsorden måske en chance for at blive virkeliggjort. Men det er dog tvivlsomt om denne revolution kan være en frigørelse, altså de handlende menneskers selvrealisering.

En socialistisk organisation må derfor heller ikke lade sig påtvinge sin struktur af den bestående orden. Hvis socialister mener, at den sociale og politiske modmagt ikke blot skal kune hamle op med modstandernes magt, men også overgå denne i form af samling og centralisering af kræfterne, i sammensvejsningen af indsatsen, i ledelsens disciplin og i nøjagtigheden af planlægningen og effektiviteten i gennemførelsen af stillede opgaver, så vil de måske sejre, men denne organisationsform og de dertil svarende kampformer vil endnu engang reproducere det bekæmpede i form og indhold. Hvis de aktive kræfter lader sig pådutte organisations- og kampformer af den magt, som de skal overvinde, så måtte man selv i tilfælde af de revolutionære kræfters sejr straks spørge, om denne sejr da afsluttede menenskehedens forhistorie eller reproducerede menneskers herredømme over mennesker på et nyt trin.

Hvad vi vil og hvordan vi når det kan ikke aflures logikken i det borgerlige

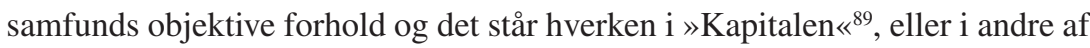
de »blå bind «. Det opstår i vores hoveder og - for at blive i billedet - i vores hjerter og ellers ingen steder. Vi må komme på sporet af det hos os selv, sætte det igennem, leve det.

89. I modsætning til den her forfægtede position tror Oscar Negt, at der i systematikken i de marxske værker absolut må findes »steder« ud fra hvilke en teori om de revolutionære processer må kunne udvikles. (Jvf. Negt, Zur Dialektik der Übergangsperiode in Westeuropa. Lelio Bassos Konzeption der revolutionåren Transformation, i Prokla nr. 34, s. 5f). 
Når den kapitalistiske vareproduktions logik ikke kan levere et grundlag for formuleringen af en socialistisk politik, fordi denne langt snarere er en »mod «politik, hvis første opgave er, at befri menneskets bevidsthed og handlen fra værdilovens tvangssammenhænge, så følger deraf også, at teorien ikke kan uddrage en eneste kategori fra analysen af den kapitalistiske vareproduktion til at definere det revolutionære subjekt med. Hvis den gør det og socialistisk politik omsætter sådanne teoretiske resultater i praksis, så har den i hvert fald overført et moment fra den gamle samfundsorden i den nye samfundsformation. Hvis den almenmenneskelige frigørelse betyder selvfrigørelse, selvbestemmelse og selvrealisering, så må det, der gør et medlem af dette samfund til et revolutionært subjekt og driver det ind $\mathrm{i}$ de revolutionære kræfters lejr, søges hos det selv. Der findes erfaringer fra tilstande, som menneskene ikke vil finde sig i, fra forhold som de vægrer sig imod, fra situationer hvor de også vover pelsen, men jeg tror ikke, at sådanne erfaringer kan almengøres.

Af den grund er arbejderklassen heller ikke defineret som det revolutionære subjekt og den kapitalistiske vareproduktions revolution kan ikke proklameres som dens historiske mission. Netop fordi proletariatet er en socio $\varnothing$ konomisk kategori i det borgerlige samfund, rejser der sig teoretiske og praktiske problemer for et socialistisk perspektiv. Lønarbejde definerer kapital - ikke systemopposition. Derfor har det også altid været muligt at transformere systemoppositionelle aktiviteter blandt arbejderne ind i modsætningen mellem kapital og lønarbejde og således afparere dem indenfor rammerne af det borgerlige samfund. Man kan bare sammenligne målet for arbejderaktionerne på I. internationales tid med de krav, der siden Socialdemokratiet er blevet et masseparti er blevet tilladt i offentlige proklamationer. Alle diskussioner om klassebevidsthedens konstitutionsbetingelser demonstrerer vanskeligheden ved at anvende en socioøkonomisk kategori revolutionsteoretisk. Det oppositionelle moment udspringer netop ikke af dette system selv. Det opstår i spændingsforholdet mellem det som menneskene ønsker og tror at kunne være, og det som de er tvunget til at være her og nu. Da Ferdinand Lasalle advarede de tyske arbejdere mod fagforeningskampens $»$ trædem $\varnothing l l e \ll^{90}$, så sigtede han netop mod sådanne overvejelser: »Der gives indenfor de muligheder samfundet stiller op ingen udvej ... af denne samfundsmæssige situation (dvs. forholdet mellem lønarbejde og kapital, A.M.). De forgæves anstrengelser for i denne sag at ville gebærde sig som menneske, er de engelske strikes (et exempel på) hvis sørgelige resultat er tilstrækkelig bekendt. Den eneste udvej for arbejder-

90. Ferdinand Lasalle, Offenes Antwortschreiben ..., i Gesammelte Reden und Schriften, udg. af Eduard Bernstein, bd. III, Berlin 1919, s. 69. 
ne kan derfor kun gå gennem den sfære indenfor hvilken de endnu tæller som mennesker ... « ${ }^{91}$.

Af disse overvejelser følger imidlertid ikke, at arbejdere, arbejdsgrupper eller måske alle arbejdere ikke kan høre til det revolutionære subjekt. At se bort fra dem ville alene være en umulighed af den grund at et fremskridt for menneskeheden i frigørende forstand slet ikke kan finde sted, hvis de revolutionære kræfter kun er en minoritet. Indenfor rammerne af den praktiske emancipationsmodel er ingen imidlertid hindret $i$, at arbejde for en samfundsorden, der overleverer menneskets magt over mennesket til historien, og dermed skaffer enhver muligheden for selvrealisering. På basis af den praktiske opfattelse af den almen-menneskelige frigørelse bestemmer det revolutionære subjekt sig selv gennem sine kampes motiver og de mål, der stræbes efter. Derfor kan en revolutionær teori heller ikke have den opgave, at dyrke betingelserne for den systemoppositionelle bevidstheds genese frem af analysen af det borgerlige samfund. Den skal tværtimod drive erkendelsen af den systemoppositionelle praksis fremad, forklare dens samfundsmæssige rødder og dens samfundsmæssige karakter og dermed muliggøre en videnskabelig fselvforståelse af den revolutionære praksis. Chancen for at en revolutionær teori, der forstås på denne måde, giver resultat synes mig at være tiltagende, for det lykkes efter min opfattelse i stadig mindre grad, at fremstille vanskelighederne i det kapitalistiske system som overvindelige. Og dermed lykkes det heller ikke at jævne bevidstheden om disse problemer og dermed heller at lede ansatser til systemopposition ind i kanaler, hvor de uden resultat sygner hen indenfor rammerne af det borgerlige samfund.

Alle forsøg på at komme til klarhed over den kritiske intelligens' opgaver indenfor rammerne af den praktiske emancipationsmodel ramler ind i et imperativ, der negativt kan formuleres som: en frigørende teori, der går ind for menneskets selvrealisering indenfor samfundsmæssige rammer, må ikke antaste individernes selvbestemmelse, men skal aktiv arbejde med på etableringen af samfundsmæssige betingelser for denne selvbestemmelse.

Positivt formuleret medfører dette imperiativ nogle paradokse konsekvenser: selvom den praktiske emancipationsmodel i modsætning til den objektivistiske opfattelse af den proletariske revolution udtrykker en formidling af teori og praksis, så kan den frigørende teori ikke præstere denne formidling. Den producerer ikke den revolutionære praksis. Den tænker den kun. Det betyder: den er teori og må vedblive at være det. Der findes to årsager til dette

91. Ferdinand Lasalle, Herr Bastiat-Schulze von Delitzsch der ökonomische Julian oder Kapital und Arbeit, i: Gesammelte Reden und Schriften, bd. V, s. 275f, note. 
postulat: En tænken der er viklet ind i praktiske kampe mister sin modstandskraft overfor partikulære bestræbelser. Transformationen af den kapitalistiske vareproduktion er imidlertid ikke en revolution, der skal bringe en eller anden partikulær gruppe, der er undertrykt indenfor det borgerlige samfund, til magten og organisere dennes interesse som det almene princip for den nye samfundsorden. Det drejer sig om den almen-menneskelige frigørelse d.v.s. om en samfundsorden, hvor menneskets herredømme over mennesket skal overgives til historien. Derfor må en tænken, der går ind for en sådan frigørelse ikke lade sig påvirke af partikulære gruppers politik og ikke bedrive teori for sådanne grupperinger. Den frigørende teori må tværtimod sikre et universalitetsprincip. Hvis det er en rigtig overbevisning, at socialismen i modsætning til kapitalismen og til de bestående socialistiske systemer i udtrykkelig forstand er en samfundsorden, der afhænger af alle deltagendes vilje og bevidsthed, så kan den kun virkeliggøres, hvis alle aktørerne bevidst kan ville og vide. En frigørende teori er nu som før nødvendig for etableringen af en sådan samfundskritisk og dermed foregribende bevidsthed om en fri samfundsorden. Derfor er også den Marxske kritik af den borgerlige samfundsorden nu som før uundværlig. Og den der imod dens egen selvforståelse fortolker den som en »politistatens videnskab « (Glucksmann) fordi der hidtil i dens navn ikke er blevet etableret det frihedens rige, der var stillet i udsigt, men en totalitær statsmagt, og som derfor tror at kunne lade den falde eller at måtte lade den falde, han fremmer netop en sådan udvikling, som han stræber efter at forhindre. Kun under forudsætning af en udfoldet samfundskritisk bevidsthed hos masserne selv - en bevidsthed, der har begrebet kernen af det, som den ikke vil og har erkendt betingelserne for det, som den vil - kan det forhindres, at der sætter sig samfundsmæssige kræfter igennem, der under dække af en usurperet almeninteresse ophøjer sine særinteresser til det almene princip for den samfundsmæssige organisering.

Den anden begrundelse for at insistere på, at formidlingen mellem teori og praksis ikke kan bedrives fra teoriens side, står i snæver sammenhæng med argumentationen ovenfor. Alligevel er en sådan forestilling drivkraften i de intellektuelles revolutionære utålmodighed. Dette fører efter min opfattelse ofte til forkerte teoretiske problemstillinger, der resulterer i lige så »fordrejede« praktiske konsekvenser. Netop derfor stiller de problemet om de materielle betingelser for opkomsten af en systemoppositionel bevidsthed og frigørende handlen, som om denne viden kunne hjælpe med til at fremskynde dannelsen af betingelserne for frigørelsen. Hvad sådanne problemstillinger kan bringe for dagens lys er ikke en frigørelse i betydningen menneskets »selv«-realisering, men realiseringen af teoretisk udarbejdede og teoretisk stillede opgaver. Således indeholder en sådan angrebsvinkel allerede i udgangspunktet teoriens 
dominans over praksis. Hvad der kan analyseres teoretisk er måske de materielle betingelser for en samfundsmæssig omvæltning. Men om en revolutionær praksis, der bliver sat i værk på baggrund af sådanne betingelser, også kan revolutionere sine egne betingelser må efter alle historiske erfaringer om revolutionære kampe og deres resultater betvivles. Betingelserne for befrielsen fra den gamle samfundsorden er altid blevet til konstitutionsbetingelser for den nye samfundsorden.

Formidlingen mellem teori og praksis fuldbyrdes altså indenfor rammerne af den praktiske emancipationsmodel ikke gennem teorien, men gennem praksis. De handlende tilegner sig resultaterne af analysen af de objektive samfundsmæssige forhold, som formidles af teorien. Dermed bliver det muligt for den at gennemskue de samfundsmæssige motiver for deres kampe og deres aspirationers samfundsmæssige karakter. Eller også bliver de kun - og det er allerede meget - sat i stand til at begribe, at grænserne for deres selvrealisering eller deres »forkrøblede liv« på forhånd er samfundsmæssig præget. Og selv om deres selvforståelse ved hjælp af den revolutionære teori endnu ikke er en forklaring på deres kampes samfundsmæssige karakter, men i første omgang bringer deres $\emptyset$ nsker og den samfundsmæssige bevidsthed om deres $\emptyset$ nsker for dagen, så har de handlende stadigvæk forrang d.v.s. det revolutionære subjekt vedbliver også i denne læreproces at være subjekt.

Og denne læreproces må begynde før starten på den kamp, der skal smide den gamle orden på møddingen, thi ellers er det atter de intellektuelle, som allerede er priviligerede indenfor det borgerlige samfund, der planlægger og beslutter den socialistiske organisation, den socialistiske strategi, og hvad der skal være socialisme. Hvorledes, ad hvilken vej, med hvilket mål bør dog ikke være spørgsmål, der skal besvares af teorien. De praktisk handlende mennesker må afgøre hvornår deres praksis skal være selvbestemmelse, selvbefrielse og selvrealisering.

På forlaget Kurasje har der tidligere været bragt flg. bidrag til diskussionen om revolutionsteori/elendiggørelsesteori: Finn Dam Rasmussen: Arbejderens situation, de sociale problemer og revolutionen. 1978. 


\section{På dansk foreligger følgende Negt-tekster og introduktioner til Negts arbejder:}

Vindrosen nr. 2-3, København, 1970, heri: Negt: Arbejderoplysning i senkapitalismen.

Negt: Offentlighet og erfaring, NSU skriftserie nr. 3, 1974, incl. indledning af Carsten Kyhn og Rolf Reitan.

Kontext (red.): Pædagogik i klassesamfundet, Kontext særhæfte, København, 1974, heri: Nils Rasmussen: Introduktion til Negts arbejderdidaktik/Negt: Det eksemplariske princip.

Kurasje nr. 10, København, 1974, heri: Negt: Teser til en marxistisk retsteori.

Negt: Sociologisk fantasi og eksemplarisk indlæring. Til teori og praksis i arbejderuddannelsen, RUC Forlag, 1975, incl. indledning til den danske udgave af Carsten Kyhn og Kai Rasmussen.

Negt: Overvejelser til en kritisk læsning af Marx og Engels, GMT, 1977, incl. indledning af Rolf Reitan.

Socialistisk Politik nr. 6, Modtryk, 1977, heri: Negt: Intet demokrati uden socialisme - ingen socialisme uden demokrati.

Kontext $n r$. 35, Modtryk, 1978, heri: Negt: Skole som erfaringsproces - samfundsmæssige aspekter af Glocksee-projektet.

Kontext $n r$. 38, Modtryk, 1979, heri: Negt: Det er ikke guldet, det er wotan der er problemet. Det nyeste oprør mod den dialektiske fornuft: Frankrigs nye filosoffer. 


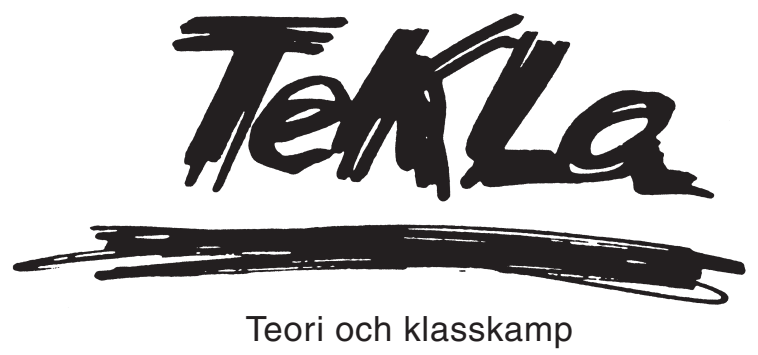

Innehåll:

\section{Nr. 6:}

- James Schmidt: Praksis och timlighet, Om Karel Kosiks politiska teori.

- Ute Volmerg: Om förhållandet mellan produktions och socialisation med det industriella lönearbetet som eksempel.

- Göran Dahl: Individ och kapital - till begripandet av den subjektiva faktorn under kapitalismen.

- Utkommer mars 1979

Nr. 7 utkommer i maj 1979 och kommer føreløbigt att inneålla en diskussion kring nyarare svensk marxistisk tradition exemplifierad med:

- Bo Gustafssons skriftstællarskap

- Mats Dahlkvists avhandlng: At studera Kapitalet

- Sven-Erik Liedman: Motsatsernas spel

- Svenska socialpolitiska analyser

Løssalgspris: $24 \mathrm{kr}$. Abbonnementspris for 4 numre: $84 \mathrm{kr}$. Abbonnement kan tegnes ved indbetaling af beløbet til Kurasje: Giro 7166044. 